\title{
Organotin(IV) complexes derived from proteinogenic amino acid: synthesis, structure and evaluation of larvicidal efficacy on Anopheles stephensi mosquito larvae
}

\author{
Basu Baul, Tushar S ; Kehie, Pelesakuo ; Höpfl, Herbert ; Duthie, Andrew ; Eng, George ; Linden, \\ Anthony
}

\begin{abstract}
Five new organotin(IV) complexes of composition [Bz2SnL1]n (), [Bz3SnL1H H2O] (), [Me2SnL2 H2O] (), [Me2SnL3] () and [Bz3SnL3H]n () (where L1 = (2S)-2-[(E)-(4-hydroxypentan-2-ylidene)]amino-4methylpentanoate, L2 = (rac)-2-[(E)-1-(2-hydroxyphenyl)methylidene]amino-4-methylpentanoate and L3 $=(2 \mathrm{~S})-$ or (rac)-2-[(E)-1-(2-hydroxyphenyl)ethylidene]amino-4-methylpentanoate) were synthesized and characterized using 1H NMR, 13C NMR, 119Sn NMR and infrared spectroscopic techniques. The crystal structure of reveals a distorted trigonal-bipyramidal geometry around the tin atom where the oxygen atoms of the carboxylate ligand and a water ligand occupy the axial positions, while the three benzyl ligands are located at the equatorial positions. On the other hand, the analogous derivative of enantiopure $\mathrm{L} 3 \mathrm{H}$ () consists of polymeric chains, in which the ligand-bridged tin atoms adopt the same trans-Bz3SnO2 trigonal-bipyramidal configuration and are now coordinated to a phenolic oxygen atom instead of $\mathrm{H} 2 \mathrm{O}$. In , the $\mathrm{OH}$ hydrogen of the ketoimine substituent has moved to the nearby nitrogen atom while in the salicylidene derivative, the $\mathrm{OH}$ is located almost midway between the phenolic oxygen atom and the nitrogen atom of the C[DOUBLE BOND]N group. For the dibenzyltin derivative , a polymeric chain structure is observed as a result of a long intermolecular Sn O bond involving the exocyclic carbonyl oxygen atom from the tridentate ligand of a neighbouring tin-complex unit. The tin atom in this complex has distorted octahedral coordination geometry. In contrast, the racemic dimethyltin(IV) complexes and display discrete monomeric structures with a distorted octahedral- and trigonal-bipyramidal geometry, respectively. The structures show that the coordination mode of the Schiff base ligand depends primarily on the number of bulky benzyl ligands $(\mathrm{R})$ at the tin atom, as indeed found in the structures of related complexes where $\mathrm{R}=$ phenyl. With three bulky $\mathrm{R}$ groups, the tridentate chelating O,N,O coordination mode is preferred, whereas with fewer or less bulky $\mathrm{R}$ ligands, only the carboxylate and hydroxy groups are involved, which leads to polymers. Larvicidal efficacies of two of the new tribenzyltin(IV) complexes ( and ) were assessed on the second larval instar of Anopheles stephensi mosquito larvae and compared with two triphenyltin(IV) analogues, $[\mathrm{Ph} 3 \mathrm{SnL} 1 \mathrm{H}] \mathrm{n}$ and $[\mathrm{Ph} 3 \mathrm{SnL} 3 \mathrm{H}] \mathrm{n}$. The results demonstrate that the compounds containing $\mathrm{Sn}-\mathrm{Ph}$ ligands are more effective than those with $\mathrm{Sn}-\mathrm{Bz}$ ligands. Copyright (C) 2016 John Wiley Sons, Ltd.
\end{abstract}

DOI: https://doi.org/10.1002/aoc.3547

Posted at the Zurich Open Repository and Archive, University of Zurich

ZORA URL: https://doi.org/10.5167/uzh-134487

Journal Article

Accepted Version 
Originally published at:

Basu Baul, Tushar S; Kehie, Pelesakuo; Höpfl, Herbert; Duthie, Andrew; Eng, George; Linden, Anthony (2017). Organotin(IV) complexes derived from proteinogenic amino acid: synthesis, structure and evaluation of larvicidal efficacy on Anopheles stephensi mosquito larvae. Applied Organometallic Chemistry, 31(1):e3547.

DOI: https://doi.org/10.1002/aoc.3547 
Organotin(IV) complexes derived from proteinogenic amino acid: Synthesis, structure and evaluation of the larvicidal efficacy on Anopheles stephensi mosquito larvae

\title{
Tushar S. Basu Baul ${ }^{a,{ }^{*}}$, Pelesakuo Kehie ${ }^{a}$, Herbert Höpfl ${ }^{b}$, Andrew Duthie ${ }^{c}$, George Eng ${ }^{d}$ and Anthony Linden ${ }^{\mathrm{e}, *}$
}

${ }^{a}$ Centre for Advanced Studies in Chemistry, North-Eastern Hill University, NEHU Permanent Campus, Umshing, Shillong 793 022, India

${ }^{b}$ Centro de Investigaciones Químicas, Universidad Autónoma del Estado de Morelos, Av. Universidad 1001, Cuernavaca 62209, Mexico

${ }^{c}$ School of Life \& Environmental Science, Deakin University, Geelong, Victoria 3217, Australia ${ }^{d}$ Division of Sciences and Mathematics, University of the District of Columbia, Washington DC 20008, USA

${ }^{e}$ Department of Chemistry, University of Zurich, Winterthurerstrasse 190, CH-8057 Zurich, Switzerland

Running title: Larvicidal activity of organotin(IV) Schiff bases derived from amino acid

\begin{abstract}
Five new organotin(IV) complexes of composition $\left[\mathrm{Bz}_{2} \mathrm{SnL}^{1}\right]_{n} \quad \mathbf{1},\left[\mathrm{Bz}_{3} \mathrm{SnL}^{1} \mathrm{H} \cdot \mathrm{H}_{2} \mathrm{O}\right] \mathbf{2}$, $\left[\mathrm{Me}_{2} \mathrm{SnL}^{2} \cdot \mathrm{H}_{2} \mathrm{O}\right] \quad 3, \quad\left[\mathrm{Me}_{2} \mathrm{SnL}^{3}\right] \quad 4$ and $\left[\mathrm{Bz}_{3} \mathrm{SnL}^{3} \mathrm{H}\right]_{\mathrm{n}} \quad \mathbf{5}$ (where $\mathrm{L}^{1}=(2 \mathrm{~S})-2-\{[(\mathrm{E})-(4-$ hydroxypentan-2-ylidene) $]$ amino $\}-4-m e t h y l p e n t a n o a t e, \quad \mathrm{~L}^{2}=(\mathrm{rac})-2-\{[(E)-1-(2-$ hydroxyphenyl)methylidene]amino $\}-4-m e t h y l p e n t a n o a t e ~ a n d ~ L^{3}=(2 S)$ - or $(r a c)-2-\{[(E)-1$ (2-hydroxyphenyl)ethylidene]amino\}-4-methylpentanoate) were synthesized and characterized by ${ }^{1} \mathrm{H},{ }^{13} \mathrm{C},{ }^{119} \mathrm{Sn}$ NMR and IR spectroscopic techniques. The crystal structure of 2 reveals a distorted trigonal-bipyramidal geometry around the tin atom where the oxygen atoms of the carboxylate ligand and a water ligand occupy the axial positions, while the three-benzyl ligands are located at the equatorial positions. On the other hand, the analogous
\end{abstract}


derivative of enantiopure $\mathrm{L}^{3} \mathrm{H}(\mathbf{5})$ consists of polymeric chains, in which the ligand-bridged Sn-atoms adopt the same trans $-\mathrm{Bz}_{3} \mathrm{SnO}_{2}$ trigonal-bipyramidal configuration and are now coordinated to a phenolic oxygen-atom instead of $\mathrm{H}_{2} \mathrm{O}$. In 2, the O-H hydrogen of the ketoimine substituent has moved to the nearby nitrogen atom while in the salicylidene derivative 5, the $\mathrm{O}-\mathrm{H}$ is located almost midway between the phenolic $\mathrm{O}$-atom and the $\mathrm{N}$-atom of the $\mathrm{C}=\mathrm{N}$ group. For the dibenzyltin derivative 1 , a polymeric chain structure is observed as a result of a long intermolecular $\mathrm{Sn} \cdots \mathrm{O}$ bond involving the exocyclic carbonyl oxygen-atom from the tridentate ligand of a neighboring Sn-complex unit. The tin atom in this complex has distorted octahedral coordination geometry. In contrast, the racemic dimethyltin(IV) complexes $\mathbf{3}$ and $\mathbf{4}$ displayed discrete monomeric structures with a distorted octahedral- and trigonal-bipyramidal geometry, respectively. The structures show that the coordination mode of the Schiff base ligand depends primarily on the number of bulky benzyl ligands $(R)$ at the $\mathrm{Sn}$ atom, as indeed found in the structures of related complexes where $\mathrm{R}=$ phenyl. With three bulky R groups, the tridentate chelating O,N,O coordination mode is preferred, whereas with fewer or less bulky R ligand, only the carboxylate and hydroxy groups are involved, which leads to polymers. Larvicidal efficacies of two new tribenzyltin(IV) complexes $\left[\mathrm{Bz}_{3} \mathrm{SnL}^{1} \mathrm{H}^{1} \mathrm{H}_{2} \mathrm{O}\right]$ (2), $\left[\mathrm{Bz}_{3} \mathrm{SnL}^{3} \mathrm{H}\right]_{\mathrm{n}}$ (5) were assessed on the second larval instar of the $A n$. Stephensi mosquito larvae and compared with two triphenyltin(IV) analogs $\left[\mathrm{Ph}_{3} \mathrm{SnL}^{1} \mathrm{H}\right]_{\mathrm{n}}$ (6) and $\left[\mathrm{Ph}_{3} \mathrm{SnL}^{3} \mathrm{H}\right]_{\mathrm{n}}$ (7). The results demonstrated that the compounds containing $\mathrm{Sn}-\mathrm{Ph}$ ligands are more effective than with Sn-Bz ligands.

Keywords Organotin(IV) aminoacetates $\cdot(S)$-2-amino-4-methylpentanoate $\cdot$ Amino acetate Schiff bases $\cdot$ Spectroscopy $\cdot$ Crystal structures $\cdot$ Toxicity $\cdot$ Larvicidal efficacy

*Corresponding authors. Tel.: +91 364 2722626; fax: +91 3642721000 (T. S. Basu Baul); Tel.: +41 44635 4228; fax: +41 446356812 (A. Linden).

E-mail addresses: basubaul@nehu.ac.in, basubaulchem@gmail.com (T. S. Basu Baul); anthony.linden@chem.uzh.ch (A. Linden). 


\section{Introduction}

Amino acids are important endogenous biological ligands that have been investigated in great detail because of their potential prospects for generating more effective and less lethal metalbased drugs. Consequently, amino acids were combined with ketones/ aldehydes to generate Schiff bases carrying an imino linkage, which developed as a promising area of investigation and their complexes were evaluated for their biological properties, such as antiproliferative, anti-inflammatory and antibacterial activities. ${ }^{[1-7]}$ 2,4-Pentanedione (acetylacetone) is a common building block for the synthesis of heterocyclic compounds and also provides increased stability to prodrugs in aqueous conditions, ${ }^{[8]}$ while 2-hydroxybenzaldehyde is a precursor of biologically important compounds such as 2-hydroxybenzoic acid (salicylic acid) or 2acetoxybenzoic acid (acetylsalicylic acid; aspirin). 2,4-Pentanedione and 2hydroxybenzaldehyde both react readily with amino acids to yield Schiff bases. Based on these antecedents, various series of organotin(IV) complexes derived from Schiff bases of amino acids, such as 2-aminoacetic-, 3-aminopropanoic-, (S)-2-amino-3-phenylpropanoic-, 2-amino-3methylbutanoic-, 2-amino-4-methylpentanoic- and 2-amino-3-hydroxypropanoic acids have been prepared and structurally characterized. ${ }^{[9-24]}$ The molecular structures of these complexes displayed varying structural features comprising both the ligand coordination modes and the metal coordination geometry, which are mainly influenced by the nature of the ligand and the Sn-R groups. Furthermore, some of the organotin(IV) complexes have also shown cytotoxic activity. ${ }^{[11,17,19-21]}$

On the other hand, it is now well known that the triorganotin(IV) compounds $\left(\mathrm{R}_{3} \mathrm{SnX}\right)$ exhibit generally the best biological activity among related series of organotin(IV) compounds of the composition $\mathrm{R}_{4-\mathrm{n}} \mathrm{SnX}_{\mathrm{n}}$, although the toxicity is shown to be species-specific. ${ }^{[25,26]}$ Thus, triorganotin(IV) compounds of the composition $\mathrm{R}_{3} \mathrm{SnX}$ ( $\mathrm{R}$ = methyl, ethyl, $n$-propyl, $n$-butyl, phenyl and cyclohexyl; $\mathrm{X}$ = anion ligand) are a widely studied class of metal-based compounds, which have been reported to be toxic against various species of mosquitoes and their larvae. Interestingly, the results suggest that the anion ligand does not play a major role for the toxicity in general, ${ }^{[27-29]}$ but they might participate in specific functions in the biological processes. ${ }^{[30-32]}$ It should also be borne in mind that triorganotin carboxylates present a variety of interesting structural features, which might have an impact in this context. Triorganotin(IV) carboxylates with bulky R groups attached to the tin atom generally adopt tetrahedral monomeric structures, while sterically less demanding $\mathrm{R}$ groups allow for the formation of polymeric structures, in which the carboxylate group bridges two tin atoms giving trigonal-bipyramidal coordination 
geometries. ${ }^{[33]}$ Previously, triorganotin(IV) compounds derived from dithiocarbamates, ${ }^{[34]}$ tris(para-substituted phenyl)tins $\left(\mathrm{X}-\mathrm{C}_{6} \mathrm{H}_{4}\right)_{3} \mathrm{SnY}$ where $\mathrm{X}=\mathrm{Cl}, \mathrm{F}, \mathrm{Me}$ and $\mathrm{SMe}$ and $\mathrm{Y}=\mathrm{Cl}, \mathrm{OH}$ and $\mathrm{OAc})^{[35]}$ and carboxylates/benzoates ${ }^{[36-45]}$ were synthesized and screened against Anopheles stephensi (An. stephensi) and Aedes aegypti (Ae. aegypti) mosquito larvae and adult mosquitoes. The results show these compounds have advantages over toxic side effects and known resistance of organophosphorus insecticides. ${ }^{[34-45]}$ Another reason for the development of organotin(IV) compounds with larvicidal activity is their biodegradability in the environment to non-toxic inorganic tin species through the progressive removal of the organic groups attached to the tin atom ${ }^{[25]}$ and lack of known resistance by the mosquito larvae. Thus, it is obvious that organotin(IV) compounds can be developed with high larvicidal activity.

As a continuation of our previous work in this area, we now report the synthesis, characterization and crystal structures of five new organotin(IV) complexes of compositions $\left[\mathrm{Bz}_{2} \mathrm{SnL}^{1}\right]_{\mathrm{n}}(\mathbf{1}),\left[\mathrm{Bz}_{3} \mathrm{SnL}^{1} \mathrm{H} \cdot \mathrm{H}_{2} \mathrm{O}\right](\mathbf{2}),\left[\mathrm{Me}_{2} \mathrm{SnL}^{2} \cdot \mathrm{H}_{2} \mathrm{O}\right](\mathbf{3}),\left[\mathrm{Me}_{2} \mathrm{SnL}^{3}\right]$ (4) and $\left[\mathrm{Bz}_{3} \mathrm{SnL}^{3} \mathrm{H}\right]_{\mathrm{n}}$ (5) where $\mathrm{L}^{1}=(2 S)-2-\{[(\mathrm{E})-(4-h y d r o x y p e n t a n-2-y l i d e n e)]$ amino $\}$-4-methylpentanoate, $\mathrm{L}^{2}=($ rac $)$ 2-\{[(E)-1-(2-hydroxyphenyl)methylidene $]$ amino $\}-4$-methylpentanoate and $\mathrm{L}^{3}=(2 S)$ - (for 5) or

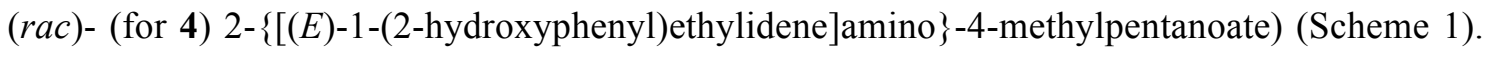
Of interest is the dependence of the coordination mode of the Schiff base ligand, L, on the number and bulk of the $\mathrm{R}$ ligands at the Sn-atom, as well as the influence of variations in $\mathrm{L}$ itself.

In addition, we examined the larvicidal potential of the tribenzyltin(IV) complexes, $\mathbf{2}$ and 5, with the expectation that the incorporation of the triorganotin moiety into the aminoacetate skeleton increases their activity due to a synergistic effect. It should be noted that until now the larvicidal potential of tribenzyltin(IV) compounds against mosquito larvae has not been assessed. Additionally, the toxicity efficacies of the tribenzyltin(IV) complexes $\mathbf{2}$ and $\mathbf{5}$ against An. stephensi mosquito larvae were compared with those of the previously reported enantiopure triphenyltin(IV) analogues $\left[\mathrm{Ph}_{3} \mathrm{SnL}^{1} \mathrm{H}\right]_{\mathrm{n}}(6)$ and $\left[\mathrm{Ph}_{3} \mathrm{SnL}^{3} \mathrm{H}\right]_{\mathrm{n}}(7) .{ }^{[21]}$

\section{Experimental}

\section{Materials and physical measurements}

$\mathrm{Bz}_{3} \mathrm{SnCl}$ and $\mathrm{Bz}_{2} \mathrm{SnCl}_{2}$ were prepared and purified by following the literature method. ${ }^{[46]}$ $\mathrm{Me}_{2} \mathrm{SnCl}_{2}$, 2'-hydroxyacetophenone (Sigma-Aldrich), (L)-2-amino-4-methylpentanoic acid (Himedia), ( $D L$ )-2-amino-4-methylpentanoic acid (Sigma-Aldrich), 2-hydroxybenzaldehyde and acetylacetone (Sisco) were used without further purification. The solvents used in the 
reactions were of $\mathrm{AR}$ grade and were dried using standard procedures. Benzene and toluene were distilled from sodium benzophenone ketyl. The syntheses, characterization data and crystal
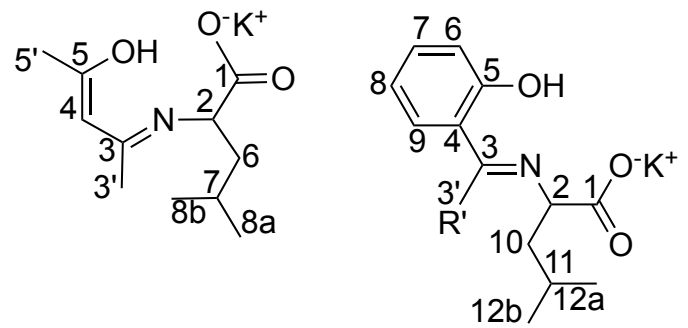

$L^{1} \mathrm{HK}$

$R^{\prime}=H: L^{2} H K ; R^{\prime}=M e: L^{3} H K$<smiles>CC(C)C[C@@H]1/N=C\c2ccccc2O[Sn](C)(C)OC1=O</smiles>

3

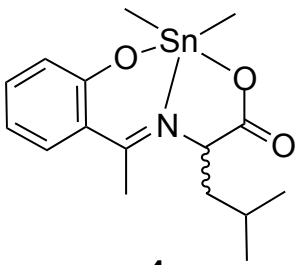

4
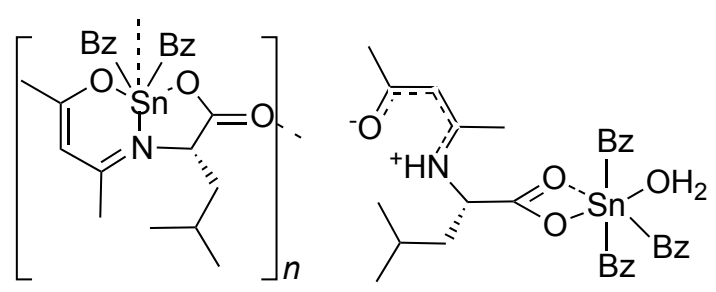

2

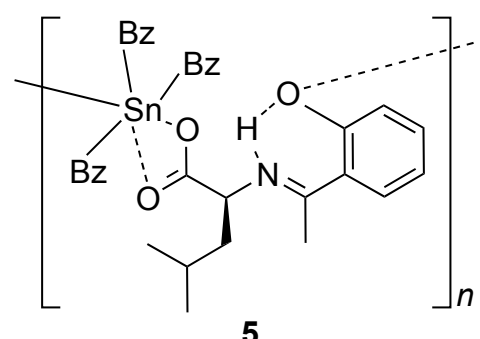

Scheme 1. The general representation of potassium salts $\left(\mathrm{L}^{1} \mathrm{HK}-\mathrm{L}^{3} \mathrm{HK}\right)$ with numbering protocol and their organotin(IV) compounds 1-5 illustrating chirality as observed in structural models.

structures of the triphenyltin(IV) complexes $\left[\mathrm{Ph}_{3} \mathrm{SnL}^{1} \mathrm{H}\right]_{\mathrm{n}} \quad$ (6) and $\left[\mathrm{Ph}_{3} \mathrm{SnL}^{3} \mathrm{H}\right]_{\mathrm{n}}$ (7) are described in ref. 21.

IR spectra in the range $4000-400 \mathrm{~cm}^{-1}$ were obtained on a Perkin Elmer Spectrum BX series FT-IR spectrophotometer with samples investigated as $\mathrm{KBr}$ discs. The ${ }^{1} \mathrm{H}$ and ${ }^{13} \mathrm{C} \mathrm{NMR}$ spectra were recorded on a Bruker AMX 400 spectrometer and measured at 400.13 and 100.62 $\mathrm{MHz}$, respectively, while ${ }^{119} \mathrm{Sn}$ NMR spectra were recorded on a Jeol GX 270 spectrometer and measured at $100.75 \mathrm{MHz}$. The ${ }^{1} \mathrm{H},{ }^{13} \mathrm{C}$ and ${ }^{119} \mathrm{Sn}$ chemical shifts were referenced to $\mathrm{Me}_{4} \mathrm{Si}, \mathrm{CDCl}_{3}$ and $\mathrm{Me}_{4} \mathrm{Sn}$ set at 0.00, 77.0 and $0.00 \mathrm{ppm}$, respectively.

\section{Synthesis of the potassium salts of the ligands}

Note: The potassium salts $\left(L^{1} H K-L^{3} H K\right)$ are dry powders when stored in vacuo, but slowly absorb moisture and turn into a paste if left in the air. Care has been taken to exclude moisture 
while recording melting points and IR spectra. The unambiguous assignments of IR bands viz., $v(O C O)_{a s y m}$ and $v(H C=N)$ could not be accomplished in the potassium salts and in their organotin(IV) complexes owing to the complex nature of spectra.

Potassium (2S)-2-\{[(E)-(4-hydroxypentan-2-ylidene)]amino\}-4-methylpentanoate $\left(\boldsymbol{L}^{1} \mathbf{H K}\right)$

A methanol solution $(5 \mathrm{ml})$ of $\mathrm{KOH}(0.18 \mathrm{~g}, 3.20 \mathrm{mmol})$ was added drop-wise to a suspension of $(L)$-2-amino-4-methylpentanoic acid $(0.42 \mathrm{~g}, 3.20 \mathrm{mmol})$ in methanol $(10 \mathrm{ml})$ with continuous stirring. After stirring for an hour, the resulting solution was filtered to remove any unreacted amino acid and dried in vacuo. The residue was treated with methanol and evaporated in vacuo to obtain potassium 2-amino-4-methylpentanoate as a dry powder. The powdered potassium salt was extracted with methanol $(20 \mathrm{ml})$, filtered and was added drop-wise to a stirred methanol solution $(2 \mathrm{ml})$ containing acetylacetone $(0.32 \mathrm{~g}, 3.19 \mathrm{mmol})$. A pale-yellow precipitate appeared almost immediately, which upon heating gave a clear solution. After reflux for $5 \mathrm{~h}$, the volatiles were removed carefully in vacuo; the residue obtained was washed with hexane, filtered and dried in vacuo. The dried residue was extracted into anhydrous methanol and evaporated on a rotary evaporator to dryness. Repeated recrystallization from methanol yielded pure $\mathrm{L}^{1} \mathrm{HK}(0.59 \mathrm{~g}, 74 \%$ yield). M.p.: $162-64{ }^{\circ} \mathrm{C}$. IR $\left(\mathrm{cm}^{-1}\right): 1599$ v(OCO) $)_{\text {asym }}$.

Potassium (rac)-2-\{[(E)-1-(2-hydroxyphenyl)methylidene]amino\}-4-methyl-pentanoate $\left(\boldsymbol{L}^{2} \mathbf{H K}\right)$

A similar synthetic procedure as for $\mathrm{L}^{1} \mathrm{HK}$ was used, except that acetylacetone and $(L)$-2-amino4-methylpentanoic acid were replaced by 2-hydroxybenzaldehyde and (DL)-2-amino-4methylpentanoic acid. After complete addition of the 2-hydroxybenzaldehyde the reaction mixture turned yellow and precipitation was noticed. The reaction mixture was then heated to reflux, giving a clear solution. After refluxing for $2 \mathrm{~h}, \mathrm{~L}^{2} \mathrm{HK}$ was isolated as yellow dry powder by following the work-up procedure described for $\mathrm{L}^{1} \mathrm{HK}$. Repeated recrystallization from methanol yielded pure $\mathrm{L}^{2} \mathrm{HK}$ in $74 \%$ yield. M.p.: $172-174{ }^{\circ} \mathrm{C}$. IR absorption $\left(\mathrm{cm}^{-1}\right)$ : 1635 $v(\mathrm{OCO})_{a s y m}$.

Potassium (2S)- and (rac)-2-\{[(E)-1-(2-hydroxyphenyl)ethylidene]amino\}-4-methyl-pentanoate $\left(\boldsymbol{L}^{3} \mathrm{HK}\right)$ 
A similar synthetic procedure as for $\mathrm{L}^{1} \mathrm{HK}$ was used, except that acetylacetone was replaced by 2'-hydroxyacetophenone and the reaction mixture was heated to reflux for $5 \mathrm{~h}$, giving a bright yellow powder from methanol solution. Repeated recrystallization from methanol afforded $(2 S)$ $\mathrm{L}^{3} \mathrm{HK}$ in $74 \%$ yield. M.p.: $170-172{ }^{\circ} \mathrm{C}$. A similar synthetic procedure to $(2 S)$ - $\mathrm{L}^{3} \mathrm{HK}$ was used for the preparation of (rac)- $\mathrm{L}^{3} \mathrm{HK}$ except that $(L)$-2-amino-4-methylpentanoic acid was replaced by $(D L)$-2-amino-4-methylpentanoic acid, giving a bright yellow powder in $45 \%$ yield. Both $(2 S)$ -

$\mathrm{L}^{3} \mathrm{HK}$ and (rac)- $\mathrm{L}^{3} \mathrm{HK}$ had identical melting points and IR spectra. IR absorption $\left(\mathrm{cm}^{-1}\right)$ : 1611 $v(\mathrm{OCO})_{a s y m}$.

\section{Synthesis of organotin(IV) complexes}

Synthesis of $\left[B z_{2} S n L^{l} H\right]_{n}(\mathbf{1})$

$\mathrm{Bz}_{2} \mathrm{SnCl}_{2}(0.50 \mathrm{~g}, 1.34 \mathrm{mmol})$ in anhydrous toluene $(20 \mathrm{ml})$ was added drop-wise to a stirred hot toluene $(30 \mathrm{ml})$ solution containing $\mathrm{L}^{1} \mathrm{HK}(0.33 \mathrm{~g}, 1.34 \mathrm{mmol})$. The reaction mixture was heated to reflux for $4 \mathrm{~h}$ and then the solvent was removed using a rotary evaporator. The pale yellow mass was washed thoroughly with hexane, dried in vacuo, extracted into chloroform and filtered. The filtrate was concentrated, precipitated with hexane and filtered. The precipitation was repeated several times in order to remove the pasty materials. The precipitate was dried in vacuo and recrystallized from benzene-hexane mixture, which afforded colorless crystalline material with a melting point of $113-115{ }^{\circ} \mathrm{C}$. Further recrystallization using the same solvent mixture yielded colorless prismatic crystals upon slow evaporation. Yield: 0.33 g (48\%). M.p.: 120-122 ${ }^{\circ}$ C. Anal. Calc. for $\mathrm{C}_{25} \mathrm{H}_{31} \mathrm{NO}_{3} \mathrm{Sn}: \mathrm{C}, 58.62 ; \mathrm{H}, 6.10 ; \mathrm{N}, 2.73 \%$. Found. C, 58.98; H, 5.90; N, 2.85\%. IR absorption $\left(\mathrm{cm}^{-1}\right): 1608 v(\mathrm{OCO})_{\text {asym. }}{ }^{1} \mathrm{H}-\mathrm{NMR}\left(\mathrm{CDCl}_{3}\right)$ : Ligand skeleton: $4.71(\mathrm{~s}, 1 \mathrm{H}$, H-4), 3.91 (dd (8.8; 5.6 Hz, 1H, H-2), 1.85-1.81 (m, 9H, H-3', H-5', H-6 and H-7), 0.91 (s, 3H, H-8a) and 0.74 (s, 3H, and H-8b); Sn-Bz skeleton: 7.19-7.11 (m, 4H, H-3*), 7.09-7.02 (m, 6H, H$4^{*}$ and $\mathrm{H}-5^{*}$ ), 2.98, 2.78 (AB system of prochiral methylene group, $4 \mathrm{H}, \mathrm{H}-1^{*}$ ) ppm. ${ }^{13} \mathrm{C}-\mathrm{NMR}$ $\left(\mathrm{CDCl}_{3}\right)$ : Ligand skeleton: 186.7 (C-1), 174.8 (C-5), 174.4 (C-3), 100.2 (C-4), 59.5 (C-2), 44.6 (C-7), 24.7 (C-6), 27.8 and 26.7 (C-8a and C-8b), 23.8 and 21.8 (C-3' and C-5'); Sn-Bz skeleton: $137.8\left(\mathrm{C}-2^{*}\right), 128.5\left(\mathrm{C}-4^{*}\right), 128.1\left(\mathrm{C}-3^{*}\right), 125.3\left(\mathrm{C}-5^{*}\right), 29.2\left(\mathrm{C}-1^{*}\right)$ ppm. ${ }^{119} \mathrm{Sn} \mathrm{NMR}\left(\mathrm{CDCl}_{3}\right)$ : $253.9 \mathrm{ppm}$. 
Synthesis of $\left[\mathrm{Bz}_{3} \mathrm{SnL} \mathrm{L}^{1} \mathrm{H} \cdot \mathrm{H}_{2} \mathrm{O}\right](2)$

$\mathrm{Bz}_{3} \mathrm{SnCl}(0.50 \mathrm{~g}, 1.16 \mathrm{mmol})$ in anhydrous toluene $(10 \mathrm{ml})$ was added drop-wise with continuous stirring to a hot anhydrous toluene $(30 \mathrm{ml})$ solution containing $\mathrm{L}^{1} \mathrm{HK}(0.29 \mathrm{~g}, 1.15 \mathrm{mmol})$. The reaction mixture was stirred for about 30 minutes and then heated to reflux for $5 \mathrm{~h}$. The reaction mixture was evaporated to dryness using a rotary evaporator. The dried residue was washed thoroughly with hot hexane to remove unreacted tin starting materials and dried in vacuo. The dried mass was then extracted into hot anhydrous chloroform $(25 \mathrm{ml})$ and filtered. The yellow filtrate was concentrated (up to one fourth of the initial solvent volume), precipitated with hexane, filtered and dried in vacuo. The crude product (M.p.: $114-116{ }^{\circ} \mathrm{C}$ ) was re-crystallized from anhydrous benzene/hexane mixture, which upon slow evaporation yielded a colorless microcrystalline product. Yield: 0.44 g (46\%). M.p.: 126-128 ${ }^{\circ} \mathrm{C}$. Anal. Calc. for $\mathrm{C}_{32} \mathrm{H}_{41} \mathrm{NO}_{4} \mathrm{Sn}$ : C, 61.76; H, 6.64; N, 2.25\%. Found. C, 61.98; H, 6.90; N, 2.35\%. IR absorption $\left(\mathrm{cm}^{-1}\right)$ : 1638 $v(\mathrm{OCO})_{\text {asym. }}{ }^{1} \mathrm{H}-\mathrm{NMR}\left(\mathrm{CDCl}_{3}\right)$ : Ligand skeleton: 10.8 (s (bifurcated), $\left.{ }^{1} J\left({ }^{1} \mathrm{H}-{ }^{15} \mathrm{~N}\right) 8.5 \mathrm{~Hz}\right), 1 \mathrm{H}, \mathrm{N}-$ $\mathrm{H} \cdots \mathrm{O}$ ), 4.95 (s, 1H, H-4), 3.92 (dd (8.8; 5.6 Hz, 1H, H-2), 1.94 and 1.73 (s, 6H, H-3' and H-5'), 1.64-1.62 (m, 1H, H-7), 1.49-1.46 (m, 2H, H-6), 0.85 (s, 3H, H-8a) and 0.90 (s, 3H, H-8b); Sn-Bz skeleton: 7.09-7.05 (m, 6H, H-3*), 6.98-6.94 (m, 3H, H-5*), 6.74-6.73 (m, 6H, H-4*), 2.56 (s, $\left.6 \mathrm{H}, \mathrm{H}-1^{*}\right)$ ppm. ${ }^{13} \mathrm{C}-\mathrm{NMR}\left(\mathrm{CDCl}_{3}\right)$ : Ligand skeleton: 195.5 (C-1), 174.9 (C-5), 162.4 (C-3), 96.1 (C-4), 55.1 (C-2), 42.0 (C-7), 24.6 (C-6), 29.0 and 19.1 (C-3' and C-5'), 23.0 and 21.7 (C-8a and C-8b); Sn-Bz skeleton: 138.7 (C-2*), $128.6\left(\mathrm{C}-4^{*}\right), 128.1$ (C-3*), 124.5 (C-5*), 24.8 (C-1*) ppm. ${ }^{119} \mathrm{Sn} \mathrm{NMR}\left(\mathrm{CDCl}_{3}\right):-6.14 \mathrm{ppm}$.

Synthesis of racemic $\left[\mathrm{Me}_{2} \mathrm{SnL}^{2} \cdot \mathrm{H}_{2} \mathrm{O}\right](3)$

$\mathrm{Me}_{2} \mathrm{SnCl}_{2}(0.25 \mathrm{~g}, 1.13 \mathrm{mmol})$ in $10 \mathrm{ml}$ benzene was added drop-wise to a hot stirred solution of racemic $\mathrm{L}^{2} \mathrm{HK}(0.31 \mathrm{~g}, 1.13 \mathrm{mmol})$ in $30 \mathrm{ml}$ benzene. The color of the reaction mixture turned immediately to bright yellow. The reaction mixture was then heated to reflux for $5 \mathrm{~h}$, filtered and dried in vacuo. The pale yellow mass was washed thoroughly with hot hexane, dried in vacuo, extracted into benzene and filtered while hot. The filtrate was allowed to evaporate at ambient temperature to leave a dry yellow mass $\left(156-158{ }^{\circ} \mathrm{C}\right)$, which was then triturated with hexane, filtered and dried in vacuo. The dried yellow mass was recrystallized from methanol to yield yellow crystals of 3 in $81 \%$ (0.35 g) yield, M.p.: $160-162{ }^{\circ}$ C. Anal. Calc. for $\mathrm{C}_{15} \mathrm{H}_{23} \mathrm{NO}_{4} \mathrm{Sn}: \mathrm{C}$, 
45.04; H, 5.79; N, 3.50\%. Found. C, 45.18; H, 6.01; N, 3.35\%. IR absorption $\left(\mathrm{cm}^{-1}\right): 1610$ $v(\mathrm{OCO})_{\text {asym. }}{ }^{1} \mathrm{H}-\mathrm{NMR}\left(\mathrm{CDCl}_{3}\right)$ : Ligand skeleton: $8.24\left(\mathrm{~s},{ }^{3} J\left({ }^{1} \mathrm{HC}=\mathrm{N}^{119 / 117} \mathrm{Sn}\right) 40 \mathrm{~Hz}\right), 1 \mathrm{H}, \mathrm{H}-3$ ' $)$, 7.44 (ddd (6.8, 6.8, $1.5 \mathrm{~Hz}) 1 \mathrm{H}, \mathrm{H}-7), 7.21$ (dd (6.5, 1.5 Hz), 1H, H-9), 6.81-6.76 (m, 2H, H-6 and $\mathrm{H}-8), 4.10$ (dd (8.8, 5.5 Hz), 1H, H-2), 1.96-1.90 and 1.65-1.60 (m, 2H, H-10), 1.82-1.71 (m, 1H, H-11), 1.01 (s, 3H, H-12a) and 1.00 (s, 3H, H-12b); Sn-Me skeleton: 0.97 (s, 3H, Sn-Me) and $0.66(\mathrm{~s}, 3 \mathrm{H}, \mathrm{Sn}-\mathrm{Me})\left({ }^{2} J\left({ }^{1} \mathrm{H}^{1}{ }^{119} \mathrm{Sn}\right) 70 \mathrm{~Hz}\right) \mathrm{ppm} .{ }^{13} \mathrm{C}-\mathrm{NMR}\left(\mathrm{CDCl}_{3}\right)$ : Ligand skeleton: $174.0(\mathrm{C}-1)$, 172.1 (C-3), 169.1 (C-5), 138.2 (C-7), 135.7 (C-9), 123.1 (C-6), 118.0 (C-8), 117.5 (C-4), 68.1 (C-2), 45.7 (C-10), 24.4 (C-11), 23.3 and 22.4 (C-12b and C-12a); Sn-Me skeleton: 1.86 and 0.78 ppm; $\left(J\left({ }^{13} \mathrm{C}_{-}{ }^{119} \mathrm{Sn}\right)=\right.$ not detected, refer to results and discussion section). ${ }^{119} \mathrm{Sn}-\mathrm{NMR}\left(\mathrm{CDCl}_{3}\right)$ :$172.5 \mathrm{ppm}$.

Synthesis of racemic $\left[\mathrm{Me}_{2} \mathrm{SnL}^{3}\right]$ (4)

An identical method to that used 3 was followed using $\mathrm{Me}_{2} \mathrm{SnCl}_{2}$ and racemic $\mathrm{L}^{3} \mathrm{HK}$, except that the complex was crystallized from benzene. Yellow crystals of compound 4 were obtained in $64 \%$ yield. M.p.: $218-220{ }^{\circ}$ C. Anal. Calc. for $\mathrm{C}_{16} \mathrm{H}_{23} \mathrm{NO}_{3} \mathrm{Sn}$ : C, 48.52; H, 5.85; N, 3.54\%. Found. C, 48.28; H, 6.09; N, 3.35\%. IR absorption $\left(\mathrm{cm}^{-1}\right)$ : $1609 v(\mathrm{OCO})_{\text {asym. }}{ }^{1} \mathrm{H}-\mathrm{NMR}\left(\mathrm{CDCl}_{3}\right)$ : Ligand skeleton: 7.49 (dd (6.5, $1.2 \mathrm{~Hz}), 1 \mathrm{H}, \mathrm{H}-6), 7.35$ (ddd (6.8, 6.8, $1.5 \mathrm{~Hz}) 1 \mathrm{H}, \mathrm{H}-7), 6.84$ (dd, 1H, (6.5, 1.5 Hz) H-9), 6.81-6.78 (m, 1H, H-8), 4.46 (dd (8.0, 4.0 Hz), 1H, H-2), 2.11-2.01 (m, 1H, H11), 1.94-1.88 and 1.55-1.49 (m, 2H, H-10), 2.65 (s, 3H, H-3'), 1.11 (s, 3H, H-12a) and 0.99 (s, 3H, H-12b); Sn-Me skeleton: 0.97 (s, 3H, Sn-Me) and 0.45 (s, 3H, Sn-Me) $\left({ }^{2} \mathrm{~J}\left({ }^{1} \mathrm{H}^{-119} \mathrm{Sn}\right) 74 \mathrm{~Hz}\right)$ ppm. ${ }^{13} \mathrm{C}-\mathrm{NMR}\left(\mathrm{CDCl}_{3}\right)$ : Ligand skeleton: 178.9 (C-1), 173.4 (C-3), 166.3 (C-5), 136.0 (C-7), 130.5 (C-9), 123.9 (C-8), 121.5 (C-4), 118.4 (C-6), 62.8 (C-2), 44.7 (C-11), 25.2 (C-10), 23.9 and 22.3 (C-12b and C-12a), 21.3 (C-3'); Sn-Me skeleton: 2.00 and $-2.44 \mathrm{ppm} ;\left(J\left({ }^{13} \mathrm{C}^{-1}{ }^{119} \mathrm{Sn}\right)=\right.$ not detected, refer to results and discussion section). ${ }^{119} \mathrm{Sn}-\mathrm{NMR}\left(\mathrm{CDCl}_{3}\right)$ : $-171.4 \mathrm{ppm}$.

Synthesis of $\left[\mathrm{Bz}_{3} \mathrm{SnL}^{3}\right]_{n}(\mathbf{5})$

An identical method to that used for 2 was followed using $\mathrm{Bz}_{3} \mathrm{SnCl}$ and enantiopure $\mathrm{L}^{3} \mathrm{HK}$. Pale yellow crystals of compound 5 were obtained in $61 \%$ yield. M.p.: $118-120{ }^{\circ} \mathrm{C}$. Anal. Calc. for $\mathrm{C}_{35} \mathrm{H}_{39} \mathrm{NO}_{3} \mathrm{Sn}: \mathrm{C}, 65.65 ; \mathrm{H}, 6.14 ; \mathrm{N}, 2.19 \%$. Found. C, 65.78; H, 5.90; N, 2.33\%. IR absorption 
$\left(\mathrm{cm}^{-1}\right): 1644 v(\mathrm{OCO})_{\text {asym. }}{ }^{1} \mathrm{H}-\mathrm{NMR}\left(\mathrm{CDCl}_{3}\right)$ : Ligand skeleton: 16.1 (br s, 1H, OH), 7.51 (dd (6.5, $1.2 \mathrm{~Hz}$ ), 1H, H-6), 7.30 (ddd (6.8, 6.8, 1.5 Hz) 1H, H-7), 6.94 (dd, 1H, (6.5, 1.5 Hz) H-9), 6.786.76 (m, 1H, H-8), 4.33 (dd (8.8, 4.0 Hz), 1H, H-2), 2.25 (s, 3H, H-3'), 1.81-1.74 (m, 2H, H-10), 1.72-1.64 (m, 1H, H-11), 0.96 (s, 3H, H-12a) and 0.87 (s, 3H, H-12b); Sn-Bz skeleton: 7.13-7.10 (m, 6H, H-3*), 7.03-7.00 (m, 3H, H-5*), 6.83-6.80 (m, 6H, H-4*), 2.62 (s, 6H, H-1*) ppm. ${ }^{13} \mathrm{C}-$ NMR ( $\mathrm{CDCl}_{3}$ ): Ligand skeleton: 176.9 (C-1), 172.2 (C-3), 164.0 (C-5), 132.7 (C-7 and C-9), 119.5 (C-4), 118.9 (C-8), 117.1 (C-6), 60,6 (C-2), 43.0 (C-11), 24.4 (C-10), 23.2 and 21.8 (C-12b and C-12a), 14.8 (C-3'); Sn-Bz skeleton: 138.5 (C-2*), 128.7 (C-4*), 127.9 (C-3*), 124.6 (C-5*), $25.0\left(\mathrm{C}-1^{*}\right)$ ppm. ${ }^{119} \mathrm{Sn}$ NMR $\left(\mathrm{CDCl}_{3}\right):-1.97 \mathrm{ppm}$.

\section{X-ray crystallography}

Crystals of the organotin(IV) complexes $\left[\mathrm{Bz}_{2} \mathrm{SnL}^{1}\right]_{\mathrm{n}}$ (1) (benzene/hexane), $\left[\mathrm{Bz}_{3} \mathrm{SnL}^{1} \mathrm{H} \cdot \mathrm{H}_{2} \mathrm{O}\right]$ (2) (benzene/hexane), $\left[\mathrm{Me}_{2} \mathrm{SnL}^{2} \cdot \mathrm{H}_{2} \mathrm{O}\right](3)$ (methanol), $\left[\mathrm{Me}_{2} \mathrm{SnL}^{3}\right]$ (4) (benzene) and $\left[\mathrm{Bz}_{3} \mathrm{SnL}^{3} \mathrm{H}\right]_{\mathrm{n}}$ (5) (benzene/hexane) suitable for single-crystal X-ray structure determination were obtained by slow evaporation of solutions of the respective complexes. Measurements of 1-3 and 5 were carried out at low temperature on a Nonius KappaCCD diffractometer ${ }^{[47]}$ with graphite-monochromated Mo $\mathrm{K} \alpha$ radiation $(\lambda=0.71073 \AA)$ and an Oxford Cryosystems Cryostream 700 cooler, while the crystal of $\mathbf{4}$ was investigated at room temperature on a Bruker APEX diffractometer with a CCD area detector (Mo K $\alpha$ radiation, $\lambda=0.71073 \AA$, graphite monochromator). Data reduction was performed with HKL Denzo and Scalepack ${ }^{[48]}$ and SAINT. ${ }^{[49]}$ Intensities were corrected for Lorentz and polarization effects, and empirical absorption corrections based on the multi-scan method $^{[50]}$ were applied. Equivalent reflections, other than the Friedel pairs for 1, 2 and 5, were merged. The data collection and refinement parameters are given in Table 1, and perspective views of the molecular structures are shown in Figs. 1, 2, 4, 5 and 6 for complexes 1, 2, 5, 4 and 3, respectively. The structures of $\mathbf{1}, \mathbf{2}$ and $\mathbf{5}$ were solved by direct methods using SIR $92^{[51]}$ while SHELXS97 ${ }^{[52]}$ was used for 3 and $\mathbf{4}$. Non-hydrogen atoms were refined anisotropically. All other $\mathrm{H}$ atoms were placed in geometrically calculated positions and refined using a riding model, where each $\mathrm{H}$ atom was assigned a fixed isotropic displacement parameter with a value equal to $1.2 U_{\text {eq }}$ of its parent $\mathrm{C}$ atom ( $1.5 U_{\text {eq }}$ for the methyl groups). The imine, hydroxy and water hydrogenatoms in $2,3,4$ and 5 were placed in the positions indicated by a difference electron density map and their positions were allowed to refine together with individual isotropic displacement parameters. In 2, the $\mathrm{O}-\mathrm{H}$ and $\mathrm{N}-\mathrm{H}$ bond lengths were restrained to $0.82(1)$ and $0.84(1) \AA$, respectively. The refinements were carried out on $F^{2}$ using full-matrix least-squares procedures, 
which minimized the function $\Sigma w\left(F_{\mathrm{o}}{ }^{2}-F_{\mathrm{c}}\right)^{2}$. Corrections for secondary extinction were applied for $\mathbf{2}$ and $\mathbf{3}$. For $\mathbf{1}$ and $\mathbf{2}$, one reflection was omitted each from the final refinement cycle, because the intensities were considered to be extreme outliers. Refinements of the absolute structure parameter [53,54] for 1, 2 and 5 yielded values of 0.01(3), 0.02(2) and -0.02(3), respectively, which confidently confirms that the refined models correspond to the true enantiomorph. For the calculations of 1-3 and 5, the SHELXL97 program $^{[52]}$ was used, while refinement and data output of 4 were carried out with the SHELXTL-NT program package. ${ }^{[5]}$ DIAMOND was used for the creation of figures. ${ }^{[56]}$

\section{Larvicidal tests}

Preparation of the organotin stock solution

Stock solutions of the triorganotin(IV) complexes 2, 5, $\mathbf{6}$ and 7, were prepared by dissolving the complexes in 95\% ethanol. The dissolution of the triorganotin(IV) complexes $\mathbf{2}, \mathbf{5}, \mathbf{6}$ and $\mathbf{7}$ in the organic media was employed to facilitate the dispersion of the complexes in water.

Note: The stabilities of the organotin(IV) complexes 2 and 5 were assessed in 95\% ethanol prior to the larvicidal studies. The absorbance obtained from UV/Vis was monitored for seven days

(Fig. S1). As can be seen, the $\lambda_{\max }$ values $(245,315 \mathrm{~nm}$ for 2 and 245, 325 and 385 for 5) did not change and the basic pattern of the spectra remained unchanged in respective cases and hence the larval toxicity studies were performed. ${ }^{[40]}$ Although, a hypochromic effect (decrease in absorbance) was observed for the band at $315 \mathrm{~nm}$ for 2 from $2 \mathrm{~h}$ onwards, which does not decay to zero. Decisive information concerning hypochromicity in $\mathbf{2}$ could not be derived at this stage. The larval toxicity data of $\mathrm{Bz}_{3} \mathrm{SnCl}$ could not be measured since the compound segregate from alcohol and water, and slowly hydrolyze while potassium salts are unstable and slowly decompose, and hence excluded from the discussion.

Larval toxicity studies

An. stephensi mosquito larvae were obtained from the Entomology Department at the Walter Reed Army Institute of Research, Washington, DC. The larvae were maintained in an environmental chamber at $27-28{ }^{\circ} \mathrm{C}$ with a humidity of $60-90 \%$ and fed with ground dog food. The larval toxicity studies were performed as described in our earlier report ${ }^{[40]}$ while Probit 
analyses ${ }^{[57]}$ were used to determine the $\mathrm{LC}_{50}$ values (concentration at which the test compounds killed $50 \%$ of the tested organisms).

\section{Results and discussion}

\section{Synthesis and spectroscopy}

For the preparation of the mono-potassium salts of ligands $\mathrm{L}^{1} \mathrm{HK}-\mathrm{L}^{3} \mathrm{HK}, \mathrm{KOH}$ was first reacted with $(L)$ - or (DL)-2-amino-4-methylpentanoic acid to avoid the formation of a zwitterionic species. The resulting potassium $(L)$ - or $(D L)$-2-amino-4-methylpentanoate was then reacted in anhydrous methanol with acetylacetone, 2-hydroxybenzaldehyde and 2'-hydroxyacetophenone, respectively, to give the potassium salts of the desired Schiff bases. Attempted preparation of $\mathrm{L}^{2} \mathrm{HK}$ using $(L)$-2-amino-4-methylpentanoic acid and 2-hydroxybenzaldehyde led to the isolation of enantiomerically pure salt in very low yield after work-up. Synthetic conveniences led to the choice of $(\mathrm{rac})-\mathrm{L}^{2} \mathrm{HK}$, which was subsequently used for the synthesis of dimethyltin(IV) compound. However, both enantiomerically pure and $(\mathrm{rac})-\mathrm{L}^{3} \mathrm{HK}$ could be isolated and they were then reacted with organotin(IV) halide(s). The salts were isolated as dry powders and remained stable in that form as powder when stored in vacuum; however, they tend to absorb moisture upon exposure to air, turning slowly into a paste of unknown composition. The potassium salts are soluble in hot benzene and toluene. From the reactions of the Schiff base potassium salts with $\mathrm{Bz}_{3} \mathrm{SnCl}$ or $\mathrm{R}_{2} \mathrm{SnCl}_{2}(\mathrm{R}=\mathrm{Me}$ or $\mathrm{Bz})$ in refluxing benzene or toluene (see experimental section for details), complexes 1-5 could be isolated in pure form in moderate yield. Of these, complexes $\mathbf{1 , 2}$ and $\mathbf{5}$, derived from the $(L)$-acid, were enantiomerically pure, while complexes $\mathbf{3}$ and $\mathbf{4}$, derived from the $(D L)$-acid, resulted in racemates, as revealed by their crystal structures. All complexes are air stable and soluble in all common organic solvents. The analytical purity of the organotin(IV) complexes was established by elemental analysis and the spectroscopic characterization was based on IR, ${ }^{1} \mathrm{H},{ }^{13} \mathrm{C}$, and ${ }^{119} \mathrm{Sn}$ NMR spectroscopic experiments.

The IR spectra of the tribenzyltin(IV) complexes $\mathbf{2}$ and $\mathbf{5}$ displayed a characteristic strong sharp band in the range 1638-1644 $\mathrm{cm}^{-1}$, while the diorganotin(IV) complexes $\mathbf{1}, 3$ and 4 displayed a band at $\sim 1610 \mathrm{~cm}^{-1}$ that has been assigned to the asymmetric carboxylate $\left[v(\mathrm{OCO})_{a s y m}\right]$ stretching vibration, in accord with our earlier reports. ${ }^{[11,15,19-21,23]}$ The ${ }^{1} \mathrm{H}$ NMR integration values of the signals and the ${ }^{13} \mathrm{C}$ NMR spectra of the complexes $\mathbf{1 - 5}$ were found to be consistent with the formulation of the products. The ${ }^{1} \mathrm{H}$ and ${ }^{13} \mathrm{C}$ NMR chemical shift assignments of the benzyl- and methyltin moieties and the ligand skeletons are straightforward from the expected shift displacements and the multiplicity patterns and/or resonance intensities and are in 
agreement with literature reports. ${ }^{[19,21]}$ The routine NMR data are summarized in experimental section, while some archetypal facts that deserve specific mention are provided here. The tribenzyltin(IV) complex 2 exhibited a bifurcated singlet signal of the intramolecular H-bonded proton $(\mathrm{O} \ldots \mathrm{H}-\mathrm{N})$ of the ligand skeleton due to scalar coupling with ${ }^{15} \mathrm{~N}$. The coupling constant ${ }^{1} J\left({ }^{1} \mathrm{H}_{-}{ }^{15} \mathrm{~N}\right)$ is $8.5 \mathrm{~Hz}$, which indicate that the proton is preferentially localized near the imino $\mathrm{N}$ atom, as shown in Scheme 1; in contrast to the spectrum of $\mathbf{5}$ where a broad singlet signal is observed due to $\mathrm{OH}$ at $\sim 16 \mathrm{ppm}$. This corroborates the fact that the ligand part of the molecule in 2 remains intact as a zwitterion, even in solution (see X-ray discussion for solid state structure). The imine hydrogen atom in complex 3 displays a sharp singlet at 8.24 ppm with a ${ }^{3} J\left({ }^{119 / 117} \mathrm{SnN}=\mathrm{C}^{1} \mathrm{H}\right)$ coupling constant of $40 \mathrm{~Hz}$. Similar coupling constants were observed for other tin complexes in which the tin nuclei are located trans to the azomethine proton, ${ }^{[23]}$ thus confirming the presence of nitrogen-tin coordination. This assumption was subsequently confirmed by the single-crystal X-ray diffraction study. The carboxylate carbon (C-1) in complexes 1-5 displayed the typical low-field shifted signal in the range $\delta 174.0$ to $195.5 \mathrm{ppm}$ in the ${ }^{13} \mathrm{C}$ NMR spectrum, which is in agreement with the data reported for analogous organotin(IV) esters. ${ }^{[19,20,23]}$ The imine carbon signal $(\mathrm{C}-3)$ for 3 was detected at $\delta 172.1 .{ }^{1} \mathrm{H}$ and ${ }^{13} \mathrm{C}$ NMR spectra of diorganotin(IV) complexes 1, 3 and $\mathbf{4}$ displayed two sets of signals for Sn-methyl and Sn-benzyl ligands owing to the presence of a stereogenic carbon at position 2, indicating the diastereotopic nature of the Sn-R groups. ${ }^{[20,21,23]}$ The poor signal-to-noise ratio in the spectrum of 3 and 4 prevented the observation of noticeable coupling $J\left({ }^{13} \mathrm{C}-{ }^{119} \mathrm{Sn}\right)$.

The coordination geometries of the complexes 1-5 in solution-state were derived from the ${ }^{119}$ Sn NMR chemical shifts. Complex 1 exhibits a single ${ }^{119}$ Sn NMR resonance at $\delta-254$ ppm, which corresponds to a five-coordinate tin center in line with the data of related systems. ${ }^{[19]}$ However, in the solid state (see X-ray discussion, vide infra) a six-coordinate metal-coordination geometry was observed for $\mathbf{1}$, which can be explained by the presence of a weak intermolecular $\mathrm{C}=\mathrm{O} \cdots \mathrm{Sn}$ interaction, giving a $1 \mathrm{D}$ polymeric chain structure. In solution, the polymer dissociates to give a monomeric species. The tribenzyltin(IV) complexes $\mathbf{2}$ and $\mathbf{5}$ exhibited sharp singlets with $\delta\left({ }^{119} \mathrm{Sn} \mathrm{NMR}\right)$ values of -6.1 and $-2.0 \mathrm{ppm}$, respectively. The values lie within the range from +55.0 to $-25.0 \mathrm{ppm}$ and are thus typical for monomeric four-coordinate tribenzyltin(IV) species in non-coordinating solvents. ${ }^{[19,58]}$ The five-coordinate solid-state structures are due to the coordination of a water molecule in $\mathbf{2}$ and a polymeric structure for $\mathbf{5}$. The dimethyltin(IV) complexes 3 and 4 exhibit single sharp resonances at around -172 and -171 ppm, respectively, with chemical shifts in the typical range for five-coordinate tin atoms. The agreement between the 
chemical shifts for $\mathbf{3}$ and $\mathbf{4}$ means that the six-coordinate Sn-atom in the solid-state structure of the aqua-complex $\mathbf{3}$ is also lost upon dissolution of that material, presumably due to loss of the aqua ligand, giving rise to a five-coordinate Sn-atom in solution. ${ }^{[1]}$

\section{Crystal structures}

The molecular structures of compounds 1-5 are shown in Figs. 1, 2, 4, 5 and 6 (see scheme 1 for line diagrams), while selected geometric parameters are collected in Tables 2-5. In the crystal structure of 1 , the asymmetric unit (Fig. S2) contains one formula unit of the Sn-complex and the units are linked into a polymeric zig-zag cis-bridged chain by a long $\operatorname{Sn}(1)-\mathrm{O}\left(2^{\prime}\right)$ bond (2.618(3) $\AA$, Table 2) involving the Sn-atom and the exocyclic carboxylate carbonyl O-atom of the tridentate $\mathrm{L}^{1}$ ligand of a neighboring Sn-complex unit (Fig. 1). The chains extend in the crystallographic $\left[\begin{array}{lll}0 & 1 & 0\end{array}\right]$ direction along a 21 screw axis. The Sn-atom has a distorted octahedral coordination geometry in which the long $\mathrm{Sn}(1)-\mathrm{O}\left(2^{\prime}\right)$ bond is almost trans to the $\mathrm{L}^{1} \mathrm{~N}$-atom, as observed for related diphenyl $\{2-\{[(E)-1-(2-$ oxyphenyl)methylidene]amino\} phenylpropionato $\} \operatorname{tin}(\mathrm{IV}) .{ }^{[20]}$ The diffraction experiment reveals that the compound in the crystal is enantiomerically pure and the ligand has the $S$-configuration, as expected from the synthetic route.

The Sn-atom in the crystal structure of tribenzyltin(V) complex 2 exhibits a trans$\mathrm{Bz}_{3} \mathrm{SnO}_{2}$ trigonal bipyramidal coordination. The axial positions are occupied by one of the $\mathrm{O}-$

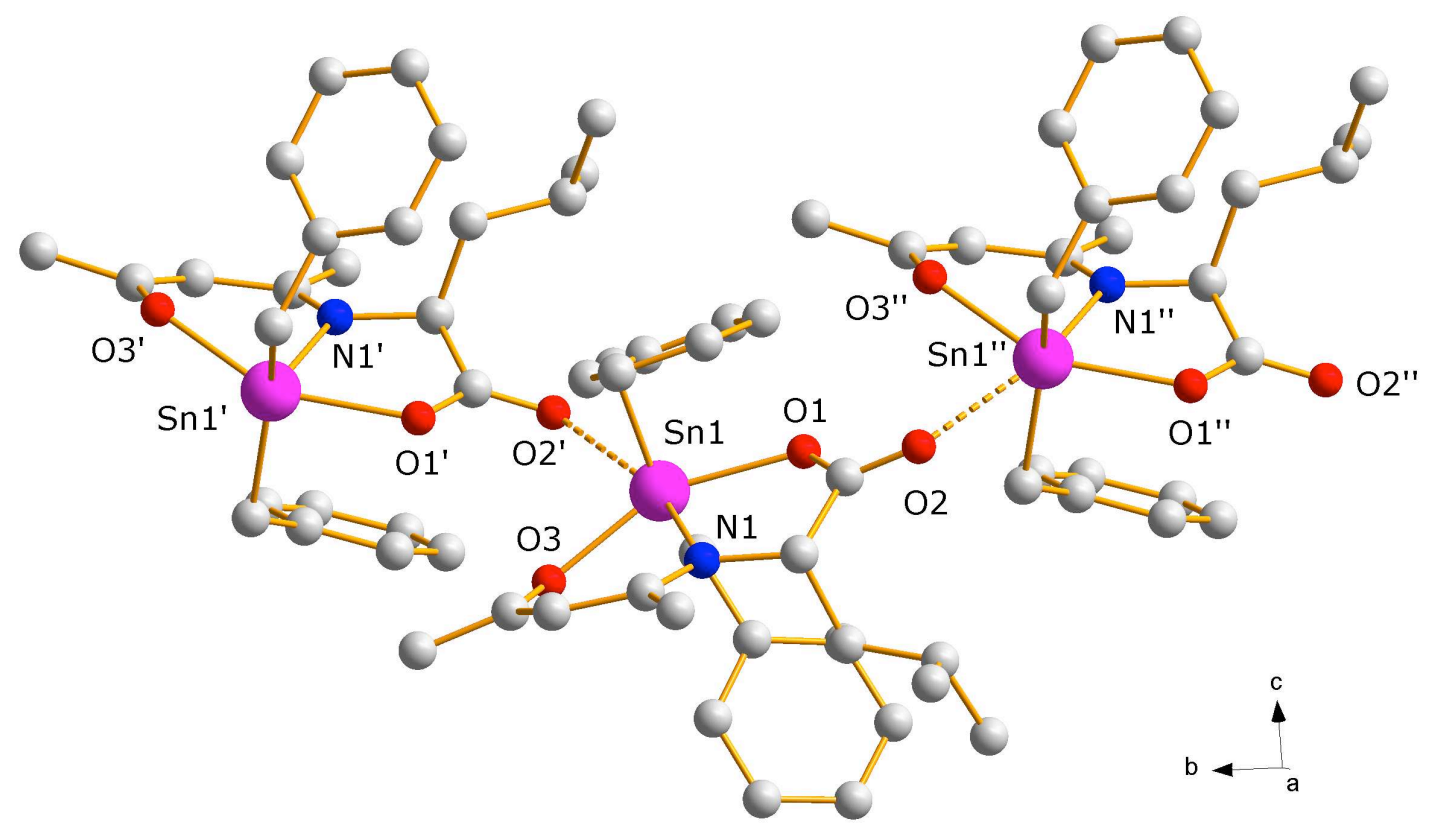


Figure 1. Three repeating units of the crystallographically and chemically unique unit in the polymeric $\left[\mathrm{Bz}_{2} \mathrm{SnL}^{1}\right]_{n}$ chain structure of $\mathbf{1}$. H-atoms omitted for clarity. Symmetry operators: ' 1-x, $\frac{1}{2}+\mathrm{y}, 2-\mathrm{z} ;$ " 1-x, $-\frac{1}{2}+\mathrm{y}, 2-\mathrm{z}$

atoms of the carboxylate ligand and the oxygen atom of a water ligand. The three-benzyl ligands occupy equatorial positions (Fig. 2). The second O-atom of the carboxylate ligand lies 3.3198(19) $\AA$ (Sn-O(2), Table 3) from the Sn-atom, but does not significantly influence the trigonal bipyramidal coordination geometry. This is in contrast to the [triphenyl $\{2-\{[(E)-(4-$ hydroxypentan-2-ylidene)]amino -4-methylpentanoato $\}$ tin(IV)) $]_{\mathrm{n}}$ analog, which is a polymer, where a single ligand bridges adjacent Sn-centres via its carboxylate and oxide O-atoms to form extended chains. $^{[21]}$ Another related example is [tribenzyl( $\{2-\{[(2 Z)-3$-hydroxy-1-methyl-2butenylidene]amino \}acetato $\}$ tin(IV)) $]_{2}$ which is a centrosymmetric dimer where two ligand molecules bridge the two tin centres. Each of the tin atoms in the dimeric unit has a trigonal bipyramidal configuration, with the benzyl carbon atoms in the equatorial positions and oxygen atoms arranged axially. ${ }^{[19]}$ Compound $\mathbf{2}$ in the crystal is enantiomerically pure and the molecule has the expected $2 S$-configuration of the carboxylate ligand. The ligand exists in a zwitterionic form as a consequence of migration of $\mathrm{H}$-atom the alcoholic group to the $\mathrm{N}$-atom of the $\mathrm{C}=\mathrm{N}$ group. The N-H group forms an intramolecular hydrogen bond with the oxide O-atom. The water ligand is also involved in two intermolecular hydrogen bonds. One interaction is with the oxide O-atom of a neighboring molecule and serves to link the molecule into extended linear chains which run parallel to the [010] direction and can be described by a graph set motif [59] of C(11). The other interaction is with the non-coordinating carboxylate $\mathrm{O}$-atom of a different neighboring molecule and serves to link the molecule into extended zig-zag chains which also run parallel to the [010] direction and can be described by a graph set motif of $\mathrm{C}(6)$. This latter interaction crosslinks the chains formed by the former interaction, so that the combination of both intermolecular hydrogen bonding interactions results in double-stranded chains of molecules running parallel to the [010] direction (Fig. 3). Within these strands, the hydrogen bonds form loops, which can be described by a graph set motif of $\mathrm{R}_{3}^{3}(17)$. 


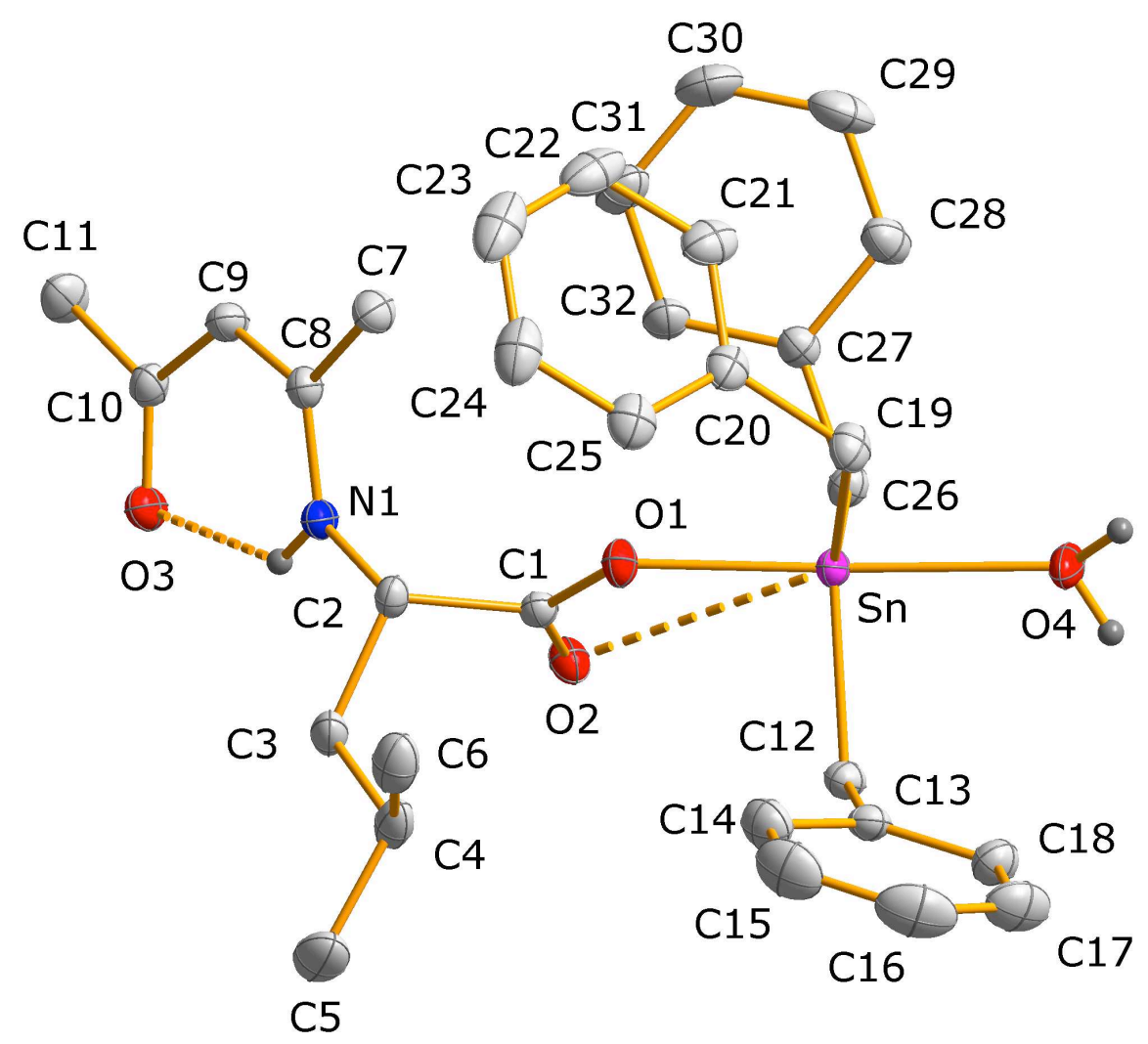

Figure 2. Molecular structure of $\left[\mathrm{Bz}_{3} \mathrm{SnL}^{1} \mathrm{H} \cdot \mathrm{H}_{2} \mathrm{O}\right] 2$ with atom-labelling scheme $(30 \%$ probability ellipsoids). Most $\mathrm{H}$-atoms omitted for clarity. 


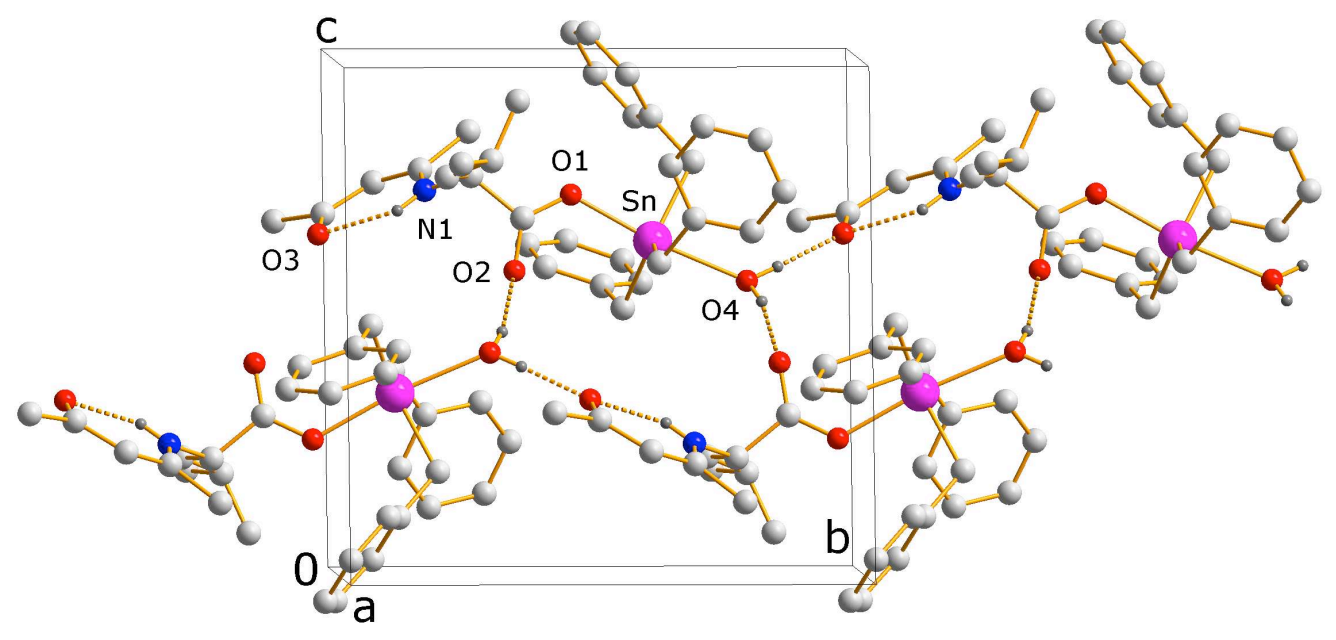

Figure 3. The molecular packing of $\mathbf{2}$ viewed down the $a$-axis showing the water ligand involved in two intermolecular hydrogen bonds (dashed lines), which link the molecules into double-stranded chains extending along the [010] direction. Most Hatoms omitted for clarity.

In contrast to the discrete monomeric structure of $\mathbf{2}$, compound $\mathbf{5}$ exhibits a polymeric chain structure where a single carboxylate ligand bridges adjacent $\mathrm{Bz}_{3} \mathrm{Sn}$ centres via its carboxylate and oxide O-atoms, as illustrated in Fig. 4. The asymmetric unit (Fig. S3) contains one of the chemical repeat units of the polymeric Sn-compound. The primary coordination sphere of the Sn-atom is trigonal bipyramidal with the benzyl ligands in the equatorial plane and the axial positions being occupied by one $\mathrm{O}$-atom from the carboxylate group of one $\mathrm{L}^{3}$ ligand and the oxide O-atom (formerly the hydroxy group) of the adjacent carboxylate ligand in the chain. The second $\mathrm{O}$-atom of the carboxylate group is not involved in the primary coordination sphere of the Sn-atom, but lies about 3.047(3) $\AA[(\mathrm{Sn}-\mathrm{O}(2)$, Table 4] from the Sn-atom. However, this interaction has no significant influence on the trigonal bipyramidal coordination geometry. Polymeric structures with a similar mode of coordination and geometry about the Sn-atom were observed in $\quad\left[\right.$ trimethyl $\{2-\{[(E)-1-(2-\text { hydroxyphenyl)methylidene }] \text { amino }\} \text { acetato }\} \text { tin(IV) }]_{\mathrm{n}}$, 
[triphenyl $\{2-\{[(E)-1-(2-h y d r o x y p h e n y l) e t h y l i d e n e]$ amino $\}$ acetato $\} \operatorname{tin}(I V)]_{\mathrm{n}}, \quad[12], \quad[\operatorname{triphenyl}(2-$ $\{[(2 Z)-(3-h y d r o x y-1 \text {-methyl-2-butenylidene) }] \text { amino }\} \text { phenylpropionato)tin(IV)) }]_{\mathrm{n}}$

[triphenyl(2-\{[(E)-1-(2-hydroxyphenyl)methylidene]amino $\}$ phenylpropionato $\} \operatorname{tin}(\mathrm{IV}))]_{\mathrm{n}} \quad$ and [triphenyl(2-\{[(E)-1-(2-hydroxyphenyl)ethylidene $]$ amino $\}$ phenylpropionato $\} \operatorname{tin}(\mathrm{IV}))]_{\mathrm{n}} \quad$ [20], [triphenyl $(\{2-\{[(E)-(4-h y d r o x y p e n t a n-2-y l i d e n e)]$ amino $\}$-4-methylpentanoato $\} \operatorname{tin}(I V))]_{\mathrm{n}}$, [triphenyl $(\{2-\{[(E)-1-(2-h y d r o x y p h e n y l) m e t h y l i d e n e]$ amino $\}-4-m e t h y l-p e n t a n o a t o\} \operatorname{tin}(I V))]_{\mathrm{n}}$ and [triphenyl( $\{2-\{[(E)-1-(2-h y d r o x y p h e n y l) e t h y l i d e n e]$ amino $\}-4-m e t h y l-p e n t a n o a t o\} \operatorname{tin}(I V))]_{\mathrm{n}}$ complexes [21]. In all these examples, the ligands are in a zwitterionic form where H-atom of the formal hydroxy group has migrated to the $\mathrm{N}$-atom of the $\mathrm{C}=\mathrm{N}$ group. In the case of $\mathbf{5}$, the $\mathrm{H}$-atom of the formal hydroxy group refines to a position almost midway between the phenolic O-atom and the $\mathrm{N}$-atom of the $\mathrm{C}=\mathrm{N}$ group (Fig. S3). This may be an artifact, though, as a difference electron density map suggests this H-atom may be disordered across two sites associated with the $\mathrm{N}$ - and the O-atoms, indicating a possible mixture of neutral and zwitterionic molecules, possibly with the latter more dominant. Attempts to refine the $\mathrm{H}$-atom in disordered positions, even with restraints, were unsuccessful, leading to negative displacement parameters. The compound in the crystal is enantiomerically pure and the stereogenic centre at $\mathrm{C}(2)$ of the molecule has the expected $S$-configuration, as confirmed from the diffraction experiment. 


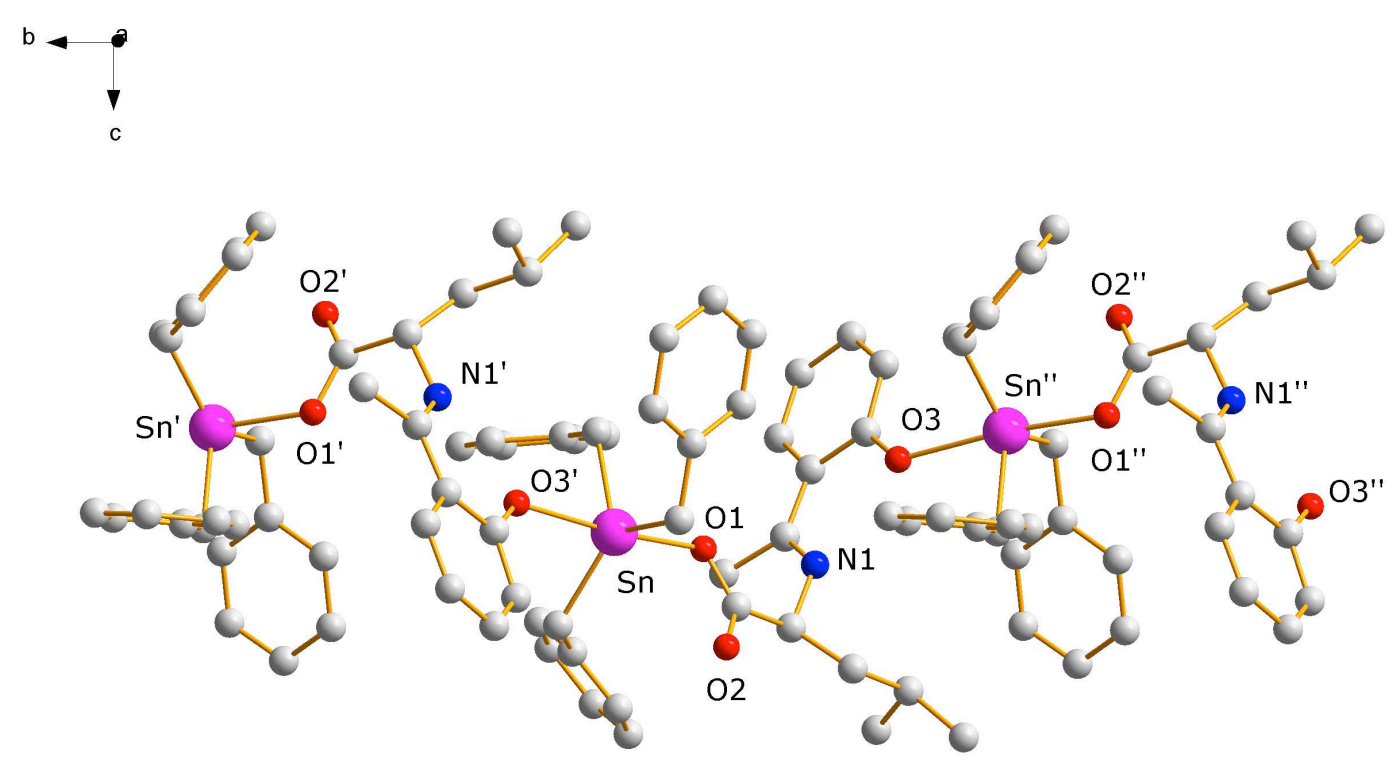

Figure 4. Three repeats of the crystallographically and chemically unique unit in the polymeric $\left[\mathrm{Bz}_{3} \mathrm{SnL}^{3} \mathrm{H}\right]_{n}$ chain structure of $\mathbf{5}$. Symmetry operators: ' -x, $\frac{1}{2}+\mathrm{y}, \frac{1}{2}-\mathrm{z} ;$ " -x, $-\frac{1}{2}+\mathrm{y}, \frac{1}{2}-\mathrm{z}$. H-atoms omitted for clarity.

The Sn-atom in compound $\mathbf{4}$ displays distorted trigonal bipyramidal coordination geometry where the racemic ligand $\mathrm{L}^{3}$ is dianionic ONO tridentate. One of the carboxylate group and oxide oxygen atoms from $\mathrm{L}^{3}$ occupy the axial positions, while the imine nitrogen atom and the carbon atoms of the two methyl groups complete the equatorial positions (Fig. 5, Table 5). Examples involving diorganotin(IV) and the Schiff bases of amino acids with a similar mode of coordination and geometry about the Sn-atom have been observed in diphenyl $\{2-\{[(E)-1-(2-$ oxyphenyl)methylidene]amino $\}$ acetato $\} \operatorname{tin}(\mathrm{IV})$ and its derivative, ${ }^{[9,10]} \operatorname{diphenyl}\{(E)-3$-hydroxy-2((2-oxybenzylidene)amino)propanoato $\} \operatorname{tin}(\mathrm{IV})$ and dimethyl/diphenyl $\{(E)-3$-hydroxy-2-((1-(2oxyphenyl)ethylidene)amino)propanoato $\} \operatorname{tin}(\mathrm{IV})^{[23]}$ complexes. 


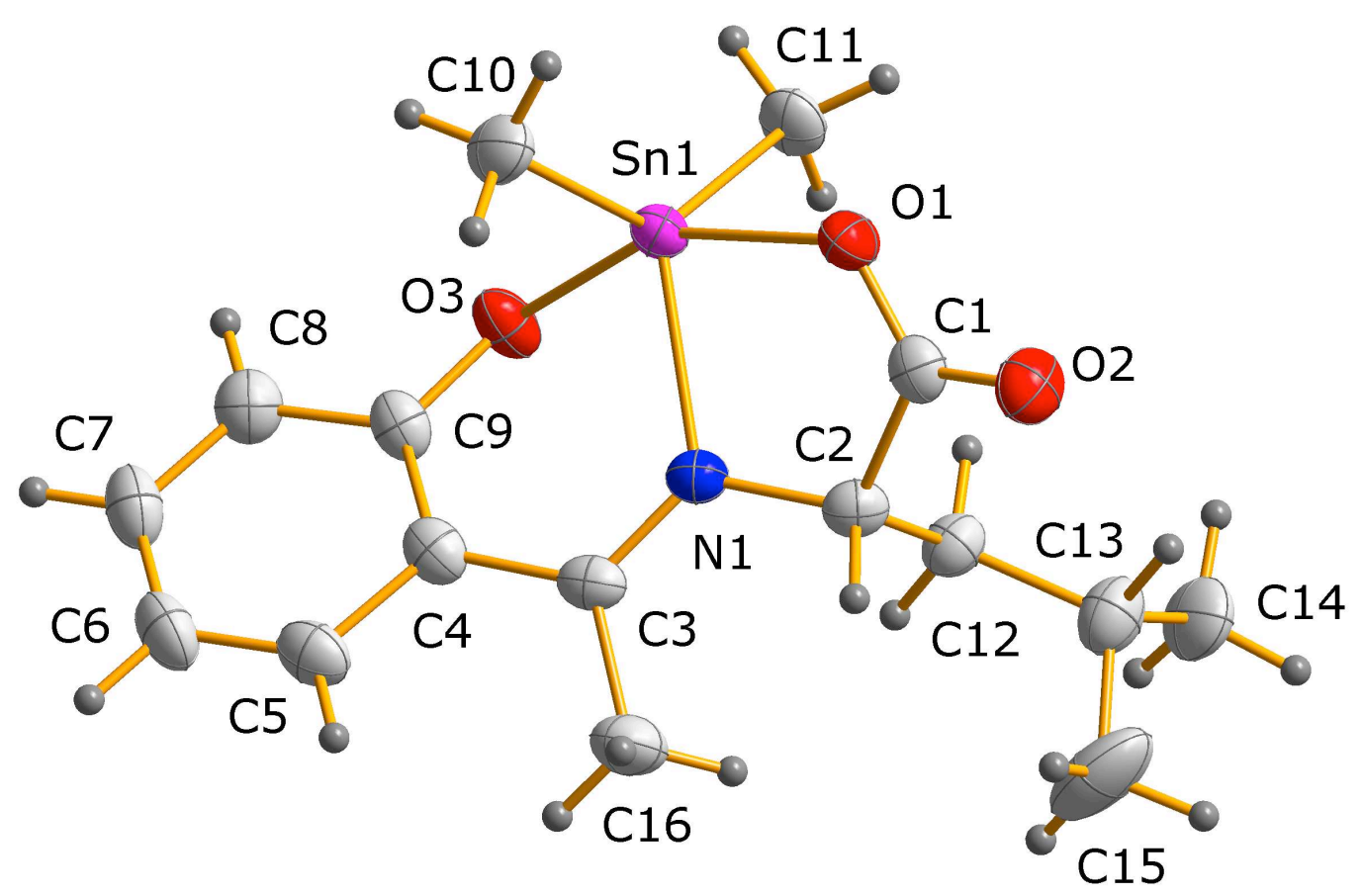

Figure 5. Molecular structure of $\left[\mathrm{Me}_{2} \mathrm{SnL}^{3}\right] 4$ with atom-labelling scheme (30\% probability ellipsoids).

In contrast to $\mathbf{4}$, the Sn-atom in the crystal structure of racemic 3 displays pseudooctahedral coordination geometry, presumably as a consequence of absorption of adventitious moisture from the solvent, with the water ligand trans to the $\mathrm{N}$-atom and the methyl ligands arranged trans to one another (Table 5). There are two molecules, A and $\mathrm{B}$, in the asymmetric unit in the crystal structure. They differ primarily in the orientation of the iso-butyl substituent; otherwise the two independent molecules have very similar geometries (Fig. 6, Table 5). Similar coordination geometries to those observed in $\mathbf{3}$ have been found in the structures of aqua divinyl $\{2-\{[(E)-1-(2-o x y p h e n y)$ ethylidene $]$ amino $\}$ acetato $\} \operatorname{tin}(\mathrm{IV})^{[9]}$ and aqua dibutyl $\{2-\{[(E)-1-$ (2-oxyphenyl)ethylidene]amino\} phenylpropionato $\}$ tin(IV). ${ }^{[20]}$ The water ligand in molecule A forms intermolecular hydrogen bonds with the carbonyl O-atom in a neighboring molecule $\mathrm{B}$ and with the phenoxide $\mathrm{O}$-atoms of a different molecule $\mathrm{B}$. In turn, the water ligand in molecule $\mathrm{B}$ forms the same types of hydrogen bonds with two adjacent molecules of A. These interactions 
link molecules A and B alternately into extended doubly bridged chains, which run parallel to the [100] direction (Table 6). The chains of A and B molecules that involve just the interactions from the water ligand of molecule A can be described by a graph set motif ${ }^{[59]}$ of $\mathrm{C}_{2}^{2}(8)$. Similarly for the chains involving only the interactions from the water ligand of molecule B (Fig. 7). The double-bridges formed by the combination of these interactions result in loops, which can be described by a graph set motif of $\mathrm{R}_{2}^{2}(10)$.

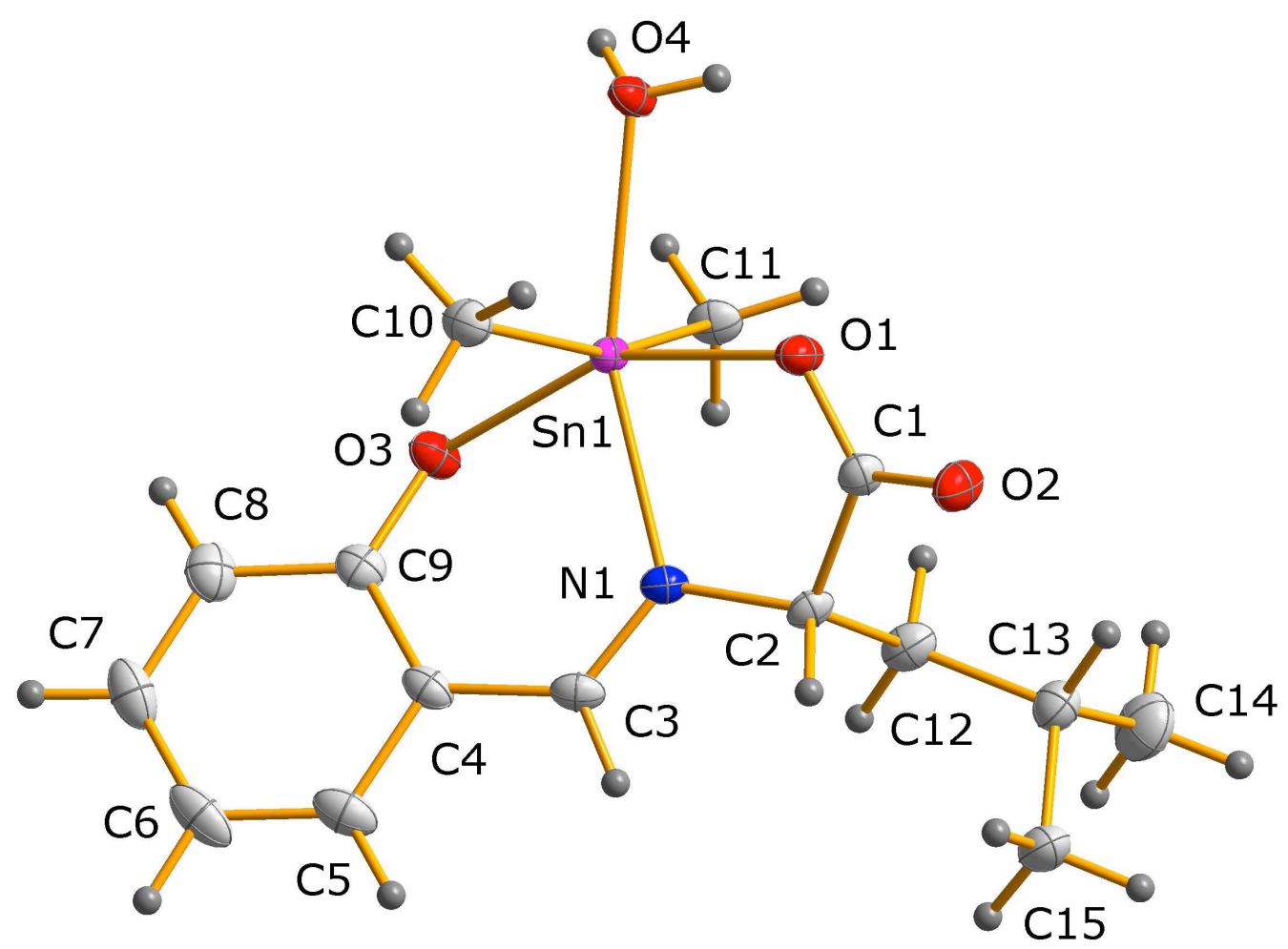

Figure 6. A view of the one of the symmetry-independent molecules (Molecule A) of $\left[\mathrm{Me}_{2} \mathrm{SnL}^{2} \cdot \mathrm{H}_{2} \mathrm{O}\right] 3$ showing the atom-labeling scheme (50\% probability ellipsoids). 


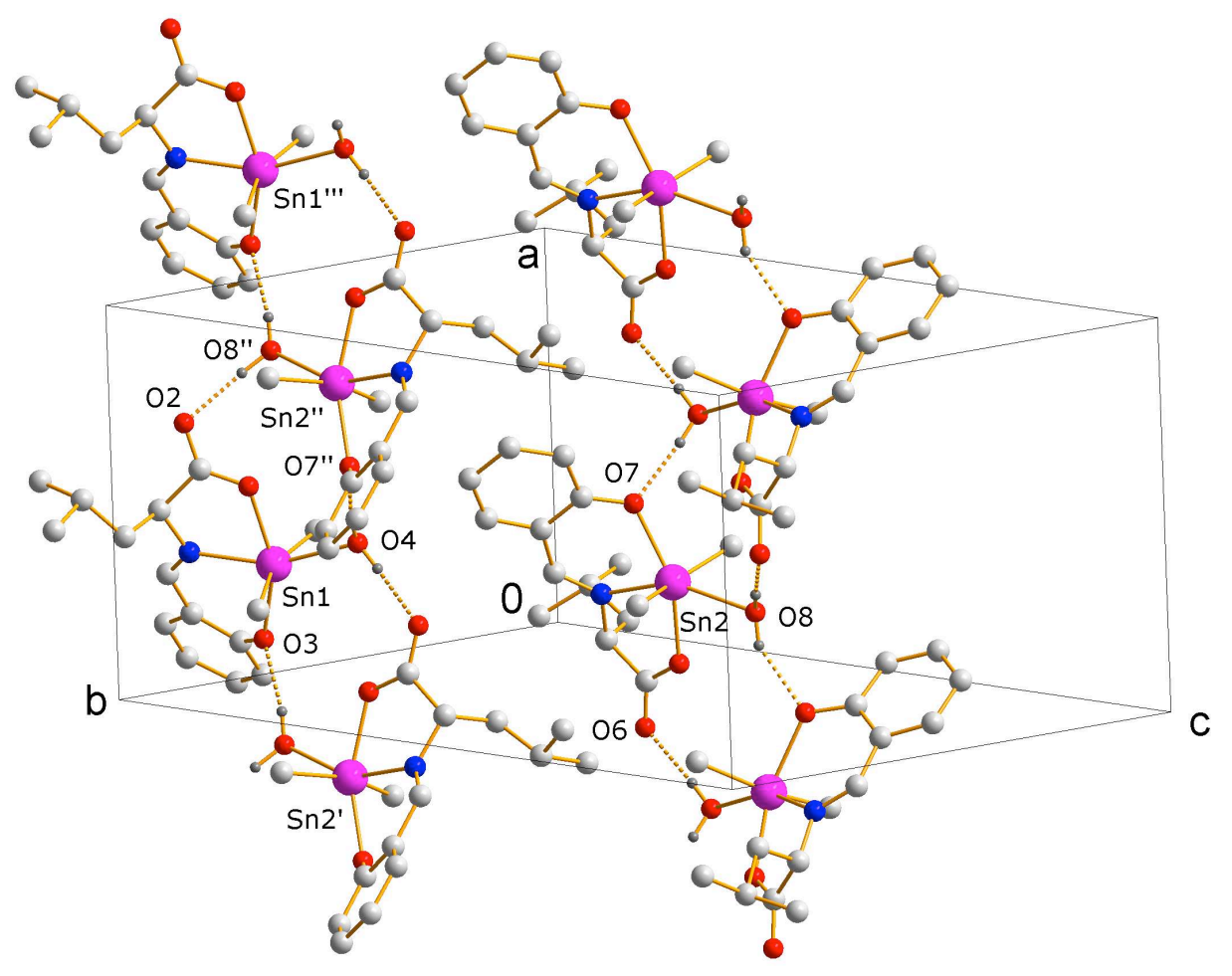

Figure 7. The molecular packing of $\mathbf{3}$ showing the water ligand in molecule A involved in intermolecular hydrogen bonds (dashed lines) with the carbonyl O-atom in a neighboring molecule $\mathrm{B}$ and with the phenoxide $\mathrm{O}$-atom of a different molecule $\mathrm{B}$ which link the molecules into extended double-bridged chains extending along the [100] direction. Symmetry operators: ' -x, $\frac{1}{2}+\mathrm{y}, \frac{1}{2}-\mathrm{z} ; \quad$ " $1-\mathrm{x}, \frac{1}{2}+\mathrm{y}, \frac{1}{2}-\mathrm{z} ; \quad$ "' $1+\mathrm{x}, \mathrm{y}, \mathrm{z}$. Most H-atoms omitted for clarity.

Comparing the five reported structures, one sees that the coordination behavior of the L ligands is flexible; they can adopt coordination modes, which may be dependent on the number and steric bulk of the other ligands coordinating to the Sn-atom. In the case of the $\mathrm{Bz}_{3} \mathrm{Sn}$ complexes 2 and 5, the L ligand prefers to coordinate to a single Sn-atom via its carboxylate group and, in the case of 5, to a second Sn-atom via its hydroxy group, because the three bulky benzyl ligands prevent the tridentate cheating $\mathrm{O}, \mathrm{N}, \mathrm{O}$ coordination mode of $\mathrm{L}$ seen in complexes $\mathbf{1 , 3}$ and 4 . In the latter three complexes, the presence of smaller, or fewer, $\mathrm{R}$ groups allows enough space for the $\mathrm{L}$ ligand to curl around the Sn-atom to give the tridentate chelating coordination mode. In the case of $\mathbf{1}$, although bulky benzyl groups are present, there are only two of them, which apparently still facilitates the tridentate chelating coordination of L, despite a sixth coordination site at the Sn- 
atom being occupied by the carboxyl O-atom of a second L ligand. The existence of additional bridging coordination of $\mathrm{L}$, as in $\mathbf{1}$ and $\mathbf{5}$, does not seem to depend on the degree of benzyl ligand congestion at the Sn atom, nor does the presence of a phenyl ring in $\mathrm{L}$ have an influence on its coordination mode. It also seems to make no difference if the final coordination number of the Sn-atom is five or six, with the sixth site occupied by fortuitous water or an O-atom of a second L ligand. Thus the determining factor on the coordination mode of the L ligands in these five complexes is primarily the presence or otherwise of three bulky benzyl ligands. These findings correlate well with similar Sn(IV) complexes with two and three phenyl ligands; those with two

phenyl ligands are similar to that of $4,{ }^{[9,10,23]}$ while those with three phenyl ligands are similar to that of $\mathbf{5}^{[12,20,21]}$

\section{Toxicity results}

The tribenzyltin(IV) complexes $\mathbf{2}$ and 5, and their triphenyltin(IV) analogs $\mathbf{6}$ and $\mathbf{7}$ having the same ligand frameworks were screened against the second larval stage of An. Stephensi mosquitoes. The $\mathrm{LC}_{50}$ values of 2, 5, 6 and 7 in parts per million (ppm), along with their standard deviations, are listed in Table 7. Recently, the larvicidal activities of $\mathrm{R}_{3} \mathrm{SnL}(\mathrm{R}=\mathrm{Me}$, Et, ${ }^{\mathrm{n}} \mathrm{Pr},{ }^{\mathrm{n}} \mathrm{Bu}, \mathrm{Ph}$ and $\mathrm{Cy} ; \mathrm{L}=$ chrysanthemumate, methylbutyrate and cyclopropane carboxylates) were described. ${ }^{[45]}$ The results were quite promising, which indicated that the toxicity mainly depends on the triorganotin(IV) compounds and the species of mosquito larvae. To our knowledge, no tribenzyltin(IV) compounds have been screened to assess the larvicidal potential of mosquitoes and hence we became interested in performing such an investigation on complexes $\mathbf{2}$ and 5. In parallel, for comparison purposes, their triphenyltin(IV) analogs 6 and 7 , whose molecular structures were determined earlier, ${ }^{[21]}$ were also chosen, because triphenyltin(IV) complexes generally demonstrated better toxicity. It should be mentioned here that the carboxylate ligands are Schiff bases which were derived from amino acids. As shown in Table 7, tribenzyltin(IV) complexes $\mathbf{2}$ and $\mathbf{5}$ and their triphenyltin(IV) analogs $\mathbf{6}$ and $\mathbf{7}$ showed the $\mathrm{LC}_{50}$ values of $\sim 15 \mathrm{ppm}$ and $\sim 6 \mathrm{ppm}$, respectively, for An. Stephensi mosquito larvae. The toxicity values are of the same order of magnitude in the respective cases. This testifies that Sn$\mathrm{R}$ group plays a major role in larvicidal activities in An. Stephensi. Although the ligand skeletons in the present investigation have no influence on the toxicity results, they might participate in specific functions in biological processes. ${ }^{[30-32]}$ It should also be borne in mind that the toxicity is also species-specific. ${ }^{[25,26]}$ Based on these observations, it is intended to search for more triphenyltin(IV) complexes with modified Schiff base ligands derived from amino acids in 
order to find improved toxicity results for An. Stephensi larvae. It is worth mentioning that triphenyltin(IV) complexes $\mathbf{6}$ and $\mathbf{7}$ have also shown promising in vitro cytotoxic results against various cancer cell lines. ${ }^{[21]}$ Further work in this area is in progress.

\section{Conclusions}

The present paper reports the syntheses, characterization and crystal structures of five organotin(IV) complexes of Schiff bases constructed from proteinogenic amino acid. Solidstate structures of the complexes (1-5) have been established from the results of single crystal $\mathrm{X}$-ray crystallography and show that the coordination mode of the Schiff base ligand depends primarily on the number of bulky benzyl ligands $(\mathrm{R})$ at the $\mathrm{Sn}$ atom, as indeed found in the structures of related complexes where $\mathrm{R}=$ phenyl. The $\delta\left({ }^{119} \mathrm{Sn} \mathrm{NMR}\right)$ data were correlated with the solution structures. Larvicidal efficacies of two new tribenzyltin(IV) complexes $\left[\mathrm{Bz}_{3} \mathrm{SnL}^{1} \mathrm{H} . \mathrm{H}_{2} \mathrm{O}\right]$ (2), $\left[\mathrm{Bz}_{3} \mathrm{SnL}^{3} \mathrm{H}\right]_{\mathrm{n}}$ (5) and two triphenyltin(IV) analogs $\left[\mathrm{Ph}_{3} \mathrm{SnL}^{1} \mathrm{H}\right]_{\mathrm{n}}$ (6) and $\left[\mathrm{Ph}_{3} \mathrm{SnL}^{3} \mathrm{H}\right]_{\mathrm{n}}$ (7) were assessed on the second larval instar of the An. Stephensi mosquito larvae. The results demonstrated that the Sn-R group plays a major role in larvicidal activities in An. stephensi, particularly when $\mathrm{R}$ is a phenyl ligand. Our studies have indicated the potential of developing compounds $\mathbf{6}$ and $\mathbf{7}$ as effective larvicidal agents. Complexes $\mathbf{6}$ and $\mathbf{7}$ displayed similar activities, regardless of their ligand frameworks, presumably due to a very similar mechanism of interaction. The advantages of developing larvicidal capabilities of organotin(IV) compounds lie in its biodegradability in the environment to non-toxic inorganic tin species and lack of known resistance by the mosquito larvae. Further work in this area is underway.

\section{Appendix A. Supplementary material}

Crystallographic data for complexes 1-5 reported in this paper have been deposited with the Cambridge Crystallographic Data Centre (CCDC) as supplementary publication no. CCDC1423179-CCDC-1423183. These data can be obtained free of charge via www.ccdc.cam.ac.uk/getstructures. Supplementary data associated with this article can be found, in the online version, at http:// XXXX. (Fig. S1: UV-Vis absorption spectra over time for tribenzyltin(IV) complexes $\left[\mathrm{Bz}_{3} \mathrm{SnL}^{1} \mathrm{H}^{1} \mathrm{H}_{2} \mathrm{O}\right] 2$ and $\left[\mathrm{Bz}_{3} \mathrm{SnL}^{3} \mathrm{H}\right]_{\mathrm{n}} \mathbf{5}$ in 95\% ethanol; Fig. S2: Perspective view of the asymmetric unit of $\mathrm{Bz}_{2} \mathrm{SnL}^{1} 1$ with the atom-labelling scheme (50\% probability ellipsoids); Fig. S3: Perspective view of the asymmetric unit of $\mathrm{Bz}_{3} \mathrm{SnL}^{3} \mathrm{H}_{5}$ with the atom-labelling scheme (50\% probability ellipsoids)). 


\section{Acknowledgements}

The financial support of the Council of Scientific and Industrial Research, New Delhi, India (Grant No. 01 (2734)/13/ EMR-II, 2013, TSBB), the University Grants Commission, New Delhi, India through SAP-CAS, Phase-I and the Indo-Swiss Joint Research Programme, Joint Utilisation of Advanced Facilities (Grant No. JUAF 11, TSBB, AL) are gratefully acknowledged. 


\section{References}

[1] C. Bartel, A. K. Bytzek, Y. Y. Scaffidi-Domianello, G. Grabmann, M. A. Jakupec, C. G. Hartinger, M. Galanski, B. K. Keppler, J. Biol. Inorg. Chem. 2012, 17, 465.

[2] R. Katwal, H. Kaur, B. K. Kapur, Sci. Revs. Chem. Commun. 2013, 3, 1.

[3] N. Berthet, V. M. Frachet, F. Michel, C. Philouze, S. Hamman, X. Ronot, F. Thomas, Dalton Trans., 2013, 42, 8468.

[4] J. Vanc $\square$ o, J. Marek, Z. Trávníc $\square$ ek, E. Rac $\square$ anská, J. Muselik, O. Švajlenová, J. Inorg. Biochem. 2008, 102, 595.

[5] P. R. Reddy, A. Shilpa, N. Raju, P. Raghavaiah, J. Inorg. Biochem. 2011,105, 1603.

[6] P. A. N. Reddy, M. Nethaji, A. R. Chakravarthy, Eur. J. Inorg. Chem. 2004, 7, 1440.

[7] M. Nath, P. K. Saini, Dalton Trans. 2011, 40, 7077.

[8] N. P. Jensen, J. J. Friedman, H. Kropp, F. M. Kahan, J. Med. Chem. 1980, 23, 6.

[9] D. Dakternieks, T. S. Basu Baul, S. Dutta, E. R. T. Tiekink, Organometallics 1998, 17, 3058.

[10] T. S. Basu Baul, E. R. T. Tiekink, Z. Kristallogr. NCS 1999, 214, 361.

[11] T. S. Basu Baul, S. Dutta, E. Rivarola, M. Scopelliti, S. Choudhuri, Appl. Organometal. Chem. 2001, 15, 947.

[12] T. S. Basu Baul, S. Dutta, E. Rivarola, R. Butcher, F. E. Smith, J. Organomet. Chem. 2002, 654, 100.

[13] T. S. Basu Baul, S. Dutta, C. Masharing, E. Rivarola, U. Englert, Heteroatom Chem. 2003,14, 149.

[14] H. I. Beltran, L. S. Zamudio-Rivera, T. Mancilla, R. Santillan, N. Farfan, Chem. Eur. J. 2003, 9, 2291.

[15] T. S. Basu Baul, C. Masharing, R. Willem, M. Biesemans, M. Holčapek, R. Jirásko, A. Linden, J. Organomet. Chem. 2005, 690, 3080.

[16] A. Linden, T. S. Basu Baul, C. Masharing, Acta Crystallogr. 2005, E61, m557.

[17] L. Tian, B. Qian, Y. Sun, X. Zheng, M. Yang, H. Li, X. Liu, Appl. Organometal. Chem. $\mathbf{2 0 0 5}, 19,980$. 
[18] T. S. Basu Baul, C. Masharing, S. Basu, E. Rivarola, M. Holčapek, R. Jirásko, A. Lyčka, D. de Vos, A. Linden, J. Organomet. Chem. 2006, 691, 952.

[19] T. S. Basu Baul, C. Masharing, E. Rivarola, F. E. Smith, R. Butcher, Struct. Chem. 2007, $18,231$.

[20] T. S. Basu Baul, C. Masharing, G. Ruisi, R. Jirásko, M. Holčapek, D. de Vos, D. Wolstenholme, A. Linden, J. Organomet. Chem. 2007, 692, 4849.

[21] T. S. Basu Baul, S. Basu, D. de Vos, A. Linden, Invest. New Drugs 2009, 27, 419.

[22] T. S. Basu Baul, P. Das, G. Eng, A. Linden, J. Inorg. Organomet. Polym. 2010, 20, 134.

[23] T. S. Basu Baul, P. Kehie, O. B. Chanu, A. Duthie, H. Höpfl, J. Organomet. Chem. 2013, $733,36$.

[24] A. Li, Ya-Hong Liu, Ling-Zhi Yuan, Zhong-Ying Ma, Chun-Lai Zhao, Cheng-Zhi Xie, Wei-Guo Bao, Jing-Yuan Xu, J. Inorg. Biochem. 2015, 146, 52.

[25] S. J. Blunden, A. Chapman, in Organometallic Compounds in the Environment: Principles and Reactions (Eds: P. J. Craig), Wiley, New York, 1986, p. 111.

[26] A. Gianguzzaa, O. Giuffrè, D. Piazzesea, S. Sammartano, Coord. Chem. Rev. 2012, 256, 222.

[27] V. G. Kumar Das, L. Y. Kuan, K. I. Sudderuddin, C. K. Chang, V. Thomas, C. K. Yap, M. K. Lo, G. C. Ong, W. K. Ng, Y. Hoi-Sen, Toxicology 1984, 32, 57.

[28] P. Castel, G. Gras, J.-A. Rioux, A. Vidal, Trav. Soc. Pharm. Montpellier 1963, 33, 45.

[29] G. Eng, C. Whitmyer, B. Sina, N. Ogwuru, Main Group Met. Chem. 1999, 22, 311.

[30] S. J. Blunden, P. A. Cusack, R. Hill, The Industrial Uses of Tin Chemicals, Royal Society of Chemistry, London, 1985, p. 23.

[31] J. Kuthubutheen, R. Wickneswari, V. G. Kumar Das, Appl. Organometal. Chem. 1989, 3, 231.

[32] S. J. Blunden, P. J. Smith, B. Sugavanam, Pestic. Sci. 1984, 15, 253.

[33] E. R. T. Tiekink, Appl. Organomet. Chem. 1991, 5, 1.

[34] G. Eng, X. Song, Q. Duong, D. Strickman, J. Glass, L. May, Appl. Organomet. Chem. 2003, 17, 218.

[35] X. Song, Q. Duong, E. Mitrojorgji, A. Zapata, N. Nguyen, D. Strickman, J. Glass, G. Eng, Appl. Organomet. Chem. 2004, 18, 363.

[36] T. T. Nguyen, N. Ogwuru, G. Eng, Appl. Organomet. Chem. 2000, 14, 345. 
[37] N. Ogwuru, Q. Duong, X. Song, G. Eng, Main Group Met. Chem. 2001, 24, 775.

[38] T. S. Basu Baul, S. Dhar, E. Rivarola, F. E. Smith, R. Butcher, X. Song, M. McCain, G. Eng, Appl. Organomet. Chem. 2003, 17, 261.

[39] T. S. Basu Baul, K. S. Singh, X. Song, A. Zapata, G. Eng, A. Lyčka, A. Linden, J. Organomet. Chem. 2004, 689, 4702.

[40] T. S. Basu Baul, K. S. Singh, M. Holčapek, R. Jirasko, A. Linden, X. Song, A. Zapata, G. Eng, Appl. Organomet. Chem. 2005, 19, 935.

[41] T. S. Basu Baul, K. S. Singh, A. Lyčka, A. linden, X. Song, A. Zapata, G. Eng, Appl. Organomet. Chem. 2006, 20, 788.

[42] X. Song, A. Zapata, J. Hoerner, A. C. de Dios, L. Casabianca, G. Eng, Appl. Organometal. Chem. 2007, 21, 545.

[43] G. Eng, X. Song, A. Zapata, A. C. de Dios, L. Casabianca, R. D. Pike, J. Organomet. Chem. 2007, 692, 1398.

[44] T. S. Basu Baul, P. Das, E. Rivarola, X. Song, G. Eng, J. Inorg. Organomet. Polym. 2010, 20, 61 .

[45] A. Zapata, D. P. Mclean, J. H. Delao Hernandez, A. C. de Dios, X. Song, G. Eng, Appl. Organometal. Chem. 2011, 25, 777.

[46] K. Sisido, T. Takeda, J. Kinigawa, J. Am. Chem. Soc. 1961, 83, 538.

[47] R. Hooft, KappaCCD Collect Software, Nonius BV, Delft, The Netherlands, 1999.

[48] Z. Otwinowski, W. Minor, in Methods in Enzymology, vol. 276, Macromolecular Crystallography, Part A (Eds: C. W. Carter Jr., R. M. Sweet), Academic Press, New York, 1997, pp. 307-326.

[49] Bruker Analytical X-ray Systems, SAINT-NT (Version 6.04), Madison, Wisconsin, USA, 2001.

[50] R. H. Blessing, Acta Crystallogr. 1995, A51, 33.

[51] A. Altomare, G. Cascarano, C. Giacovazzo, A. Guagliardi, M. C. Burla, G. Polidori, M. Camalli, SIR92, J. Appl. Crystallogr. 1994, 27, 435.

[52] G. M. Sheldrick, SHELXL97 and SHELXS97, Acta Crystallogr. 2008, A64, 112. 
[53] H. D. Flack, G. Bernardinelli, Acta Crystallogr. 1999, A55, 908.

[54] H. D. Flack, G. Bernardinelli, J. Appl. Crystallogr. 2000, 33, 1143.

[55] Bruker Analytical X-ray Systems, SHELXTL-NT (Version 6.10), Madison, Wisconsin, USA, 2000.

[56] K. Brandenburg, DIAMOND, Version 3.1c, Crystal Impact GbR, Bonn, Germany, 1997.

[57] D. J. Finney, Probit Analysis: A Treatment of the Sigmoid Curve Response, $3^{\text {rd }}$ ed., Cambridge University Press, London, UK, 1971.

[58] A. Lyčka, J. Jirman, A. Kolonicny, J. Holeček, J. Organomet. Chem. 1987, 333, 305.

[59] J. Bernstein, R. E. Davis, L. Shimoni, N.-L. Chang, Angew. Chem. 1995, 107, 1689; Angew. Chem. Int. Ed. Engl. 1995, 34, 1555. 
Table 1. Crystallographic data and structure refinement parameters for organotin(IV) complexes 1-5

\begin{tabular}{|c|c|c|c|c|c|}
\hline & 1 & 2 & 3 & 4 & 5 \\
\hline Empirical formula & $\mathrm{C}_{25} \mathrm{H}_{31} \mathrm{NO}_{3} \mathrm{Sn}$ & $\mathrm{C}_{32} \mathrm{H}_{41} \mathrm{NO}_{4} \mathrm{Sn}$ & $\mathrm{C}_{15} \mathrm{H}_{23} \mathrm{NO}_{4} \mathrm{Sn}$ & $\mathrm{C}_{16} \mathrm{H}_{23} \mathrm{NO}_{3} \mathrm{Sn}$ & $\mathrm{C}_{35} \mathrm{H}_{39} \mathrm{NO}_{3} \mathrm{Sn}$ \\
\hline Formula weight & 512.12 & 622.28 & 399.95 & 396.04 & 640.30 \\
\hline Crystal size (mm) & $0.13 \times 0.18 \times 0.25$ & $0.10 \times 0.20 \times 0.25$ & $0.15 \times 0.15 \times 0.30$ & $0.12 \times 0.32 \times 0.38$ & $0.10 \times 0.15 \times 0.25$ \\
\hline Crystal morphology & Prism & Tablet & Prism & Prism & Prism \\
\hline Temperature (K) & $160(1)$ & $160(1)$ & $160(1)$ & $293(2)$ & $160(1)$ \\
\hline Crystal system & Monoclinic & Monoclinic & Monoclinic & Monoclinic & Orthorhombic \\
\hline Space group & $P 2_{1}$ & $P 2_{1}$ & $P 2_{1} / \mathrm{c}$ & $P 2_{1} / \mathrm{c}$ & $P 2_{1} 2_{1} 2_{1}$ \\
\hline$a(\AA)$ & $9.4818(1)$ & $10.9806(2)$ & $9.8152(1)$ & $11.6800(9)$ & $11.4643(2)$ \\
\hline$b(\AA)$ & $11.4277(2)$ & $12.0561(2)$ & $17.0254(2)$ & $11.1748(9)$ & $15.1122(2)$ \\
\hline$c(\AA)$ & $11.2620(2)$ & $12.2091(2)$ & $19.6522(2)$ & $13.3757(11)$ & $17.9735(2)$ \\
\hline$\beta\left(^{\circ}\right)$ & $108.9532(9)$ & $105.893(1)$ & $93.6776(5)$ & $104.3210(10)$ & 90 \\
\hline$V\left(\AA^{3}\right)$ & $1154.14(3)$ & $1554.50(5)$ & $3277.27(6)$ & $1691.6(2)$ & $3113.92(8)$ \\
\hline$Z$ & 2 & 2 & 8 & 4 & 4 \\
\hline$D x\left(\mathrm{~g} \mathrm{~cm}^{-3}\right)$ & 1.474 & 1.329 & 1.621 & 1.555 & 1.366 \\
\hline$\mu\left(\mathrm{mm}^{-1}\right)$ & 1.131 & 0.855 & 1.572 & 1.519 & 0.854 \\
\hline $\begin{array}{l}\text { Transmission factors } \\
(\min , \max )\end{array}$ & $0.752,0.876$ & $0.736,0.919$ & $0.651,0.795$ & $0.596,0.839$ & $0.815,0.922$ \\
\hline$\theta$ range $\left(^{\circ}\right)$ & $2.6-30.0$ & $2.2-30.1$ & $2.1-30.0$ & $1.8-25.0$ & $2.1-30.0$ \\
\hline Reflections measured & 29435 & 43921 & 85104 & 15902 & 58135 \\
\hline $\begin{array}{l}\text { Independent reflections; } \\
R_{\text {int }}\end{array}$ & $6679 ; 0.060$ & $9051 ; 0.062$ & $9551 ; 0.068$ & $2969 ; 0.039$ & $9105 ; 0.100$ \\
\hline Reflections with $I>2 \sigma(I)$ & 6381 & 8164 & 8209 & 2741 & 7379 \\
\hline Number of parameters & 275 & 360 & 404 & 195 & 368 \\
\hline Number of restraints & 1 & 4 & 0 & 0 & 0 \\
\hline$R(F)[I>2 \sigma(I) \mathrm{reflns}]$ & 0.044 & 0.035 & 0.038 & 0.053 & 0.051 \\
\hline$w R\left(F^{2}\right)$ (all data) & 0.110 & 0.079 & 0.097 & 0.126 & 0.123 \\
\hline $\operatorname{GOF}\left(F^{2}\right)$ & 1.12 & 1.13 & 1.07 & 1.06 & 1.05 \\
\hline$\Delta \rho \max , \min \left(\mathrm{e} \AA^{-3}\right)$ & $1.10,-2.27$ & $1.30 ;-0.61$ & $1.04 ;-1.17$ & $0.84,-1.05$ & $0.71,-2.20$ \\
\hline
\end{tabular}


Table 2. Selected bond lengths $(\AA)$ and angles $\left({ }^{\circ}\right)$ for complex $\mathbf{1}^{\text {a }}$

\begin{tabular}{ll}
\hline $\mathrm{Sn}(1)-\mathrm{O}(1)$ & $2.212(3)$ \\
$\mathrm{Sn}(1)-\mathrm{O}(3)$ & $2.107(3)$ \\
$\mathrm{Sn}(1)-\mathrm{O}\left(2^{\prime}\right)$ & $2.618(3)$ \\
$\mathrm{Sn}(1)-\mathrm{N}(1)$ & $2.173(3)$ \\
$\mathrm{Sn}(1)-\mathrm{C}(10)$ & $2.136(4)$ \\
$\mathrm{Sn}(1)-\mathrm{C}(11)$ & $2.148(4)$ \\
& \\
$\mathrm{O}(1)-\mathrm{Sn}(1)-\mathrm{C}(10)$ & $88.47(13)$ \\
$\mathrm{O}(1)-\mathrm{Sn}(1)-\mathrm{C}(11)$ & $91.38(15)$ \\
$\mathrm{O}(1)-\mathrm{Sn}(1)-\mathrm{O}(3)$ & $153.93(12)$ \\
$\mathrm{O}(1)-\mathrm{Sn}(1)-\mathrm{N}(1)$ & $74.89(12)$ \\
$\mathrm{O}(3)-\mathrm{Sn}(1)-\mathrm{C}(10)$ & $88.27(14)$ \\
$\mathrm{O}(3)-\mathrm{Sn}(1)-\mathrm{C}(11)$ & $105.95(16)$ \\
$\mathrm{N}(1)-\mathrm{Sn}(1)-\mathrm{C}(10)$ & $116.39(14)$ \\
$\mathrm{N}(1)-\mathrm{Sn}(1)-\mathrm{C}(11)$ & $97.58(14)$ \\
$\mathrm{C}(10)-\mathrm{Sn}(1)-\mathrm{C}(11)$ & $144.64(15)$ \\
\hline
\end{tabular}

${ }^{\text {a }}$ Primed atoms refer to atoms from the next symmetrically-related ligand in the polymeric chain (symmetry code: $1-x, \frac{1}{2}+y, 2-z$ ). 
Table 3. Selected bond lengths $(\AA)$ and angles $\left({ }^{\circ}\right)$ for complex 2

\begin{tabular}{ll}
\hline $\mathrm{Sn}-\mathrm{O}(1)$ & $2.1642(18)$ \\
$\mathrm{Sn}-\mathrm{O}(4)$ & $2.363(2)$ \\
$\mathrm{Sn}-\mathrm{O}(2)$ & $3.3198(19)$ \\
$\mathrm{Sn}-\mathrm{C}(12)$ & $2.151(2)$ \\
$\mathrm{Sn}-\mathrm{C}(19)$ & $2.147(3)$ \\
$\mathrm{Sn}-\mathrm{C}(26)$ & $2.149(3)$ \\
& \\
$\mathrm{C}(12)-\mathrm{Sn}-\mathrm{C}(19)$ & $119.18(12)$ \\
$\mathrm{C}(12)-\mathrm{Sn}-\mathrm{C}(26)$ & $117.24(10)$ \\
$\mathrm{C}(19)-\mathrm{Sn}-\mathrm{C}(26)$ & $122.22(12)$ \\
$\mathrm{O}(1)-\mathrm{Sn}-\mathrm{O}(4)$ & $173.63(7)$ \\
$\mathrm{O}(1)-\mathrm{Sn}-\mathrm{C}(12)$ & $93.96(13)$ \\
$\mathrm{O}(1)-\mathrm{Sn}-\mathrm{C}(19)$ & $89.58(9)$ \\
$\mathrm{O}(1)-\mathrm{Sn}-\mathrm{C}(26)$ & $98.14(9)$ \\
\hline
\end{tabular}


Table 4. Selected bond lengths $(\AA)$ and angles $\left(^{\circ}\right)$ for complex $\mathbf{5}^{\text {a }}$

\begin{tabular}{ll}
\hline $\mathrm{Sn}-\mathrm{O}(1)$ & $2.181(3)$ \\
$\mathrm{Sn}-\mathrm{O}\left(3^{\prime}\right)$ & $2.322(3)$ \\
$\mathrm{Sn}-\mathrm{O}(2)$ & $3.047(3)$ \\
$\mathrm{Sn}-\mathrm{C}(14)$ & $2.165(4)$ \\
$\mathrm{Sn}-\mathrm{C}(21)$ & $2.160(4)$ \\
$\mathrm{Sn}-\mathrm{C}(28)$ & $2.156(4)$ \\
& \\
$\mathrm{C}(14)-\mathrm{Sn}-\mathrm{C}(21)$ & $110.90(17)$ \\
$\mathrm{C}(14)-\mathrm{Sn}-\mathrm{C}(28)$ & $127.73(19)$ \\
$\mathrm{C}(21)-\mathrm{Sn}-\mathrm{C}(28)$ & $120.72(18)$ \\
$\mathrm{O}(1)-\mathrm{Sn}-\mathrm{O}\left(3^{\prime}\right)$ & $173.44(11)$ \\
\hline
\end{tabular}

${ }^{a}$ Primed atoms refer to atoms from the next symmetrically-related ligand in the polymeric chain (symmetry code: $-x, \frac{1}{2}+y, \frac{1}{2}-z$ ). 
Table 5. Selected bond lengths $(\AA)$ and angles $\left({ }^{\circ}\right)$ for complexes 3 and $\mathbf{4}$

\begin{tabular}{|c|c|c|c|c|}
\hline \multicolumn{4}{|c|}{3} & \multirow{3}{*}{$\begin{array}{c}4 \\
2.150(4)\end{array}$} \\
\hline \multicolumn{2}{|c|}{ Molecule A } & \multicolumn{2}{|c|}{ Molecule B } & \\
\hline $\mathrm{Sn}(1)-\mathrm{O}(1)$ & $2.168(2)$ & $\mathrm{Sn}(2)-\mathrm{O}(5)$ & $2.167(2)$ & \\
\hline $\mathrm{Sn}(1)-\mathrm{O}(3)$ & $2.188(2)$ & $\operatorname{Sn}(2)-O(7)$ & $2.1788(19)$ & $2.085(4)$ \\
\hline $\mathrm{Sn}(1)-\mathrm{O}(4)$ & $2.420(2)$ & $\mathrm{Sn}(2)-\mathrm{O}(8)$ & $2.463(2)$ & - \\
\hline $\operatorname{Sn}(1)-N(1)$ & $2.226(2)$ & $\mathrm{Sn}(2)-\mathrm{N}(2)$ & $2.242(2)$ & $2.176(5)$ \\
\hline $\operatorname{Sn}(1)-C(10)$ & $2.107(3)$ & $\operatorname{Sn}(2)-C(30)$ & $2.108(3)$ & $2.092(7)$ \\
\hline $\operatorname{Sn}(1)-C(11)$ & $2.111(3)$ & $\operatorname{Sn}(2)-C(31)$ & $2.104(3)$ & $2.105(6)$ \\
\hline $\mathrm{O}(1)-\mathrm{Sn}(1)-\mathrm{C}(10)$ & $93.90(11)$ & $\mathrm{O}(5)-\mathrm{Sn}(2)-\mathrm{C}(30)$ & $95.42(11)$ & $94.4(3)$ \\
\hline $\mathrm{O}(1)-\mathrm{Sn}(1)-\mathrm{C}(11)$ & $97.31(11)$ & $\mathrm{O}(5)-\mathrm{Sn}(2)-\mathrm{C}(31)$ & $97.28(11)$ & $93.1(2)$ \\
\hline $\mathrm{O}(1)-\mathrm{Sn}(1)-\mathrm{O}(3)$ & $154.55(8)$ & $\mathrm{O}(5)-\mathrm{Sn}(2)-\mathrm{O}(7)$ & $152.27(8)$ & $154.79(18)$ \\
\hline $\mathrm{O}(1)-\mathrm{Sn}(1)-\mathrm{N}(1)$ & $74.01(8)$ & $\mathrm{O}(5)-\mathrm{Sn}(2)-\mathrm{N}(2)$ & $73.37(8)$ & $75.03(17)$ \\
\hline $\mathrm{O}(3)-\mathrm{Sn}(1)-\mathrm{C}(10)$ & $89.17(11)$ & $\mathrm{O}(7)-\mathrm{Sn}(2)-\mathrm{C}(30)$ & $90.11(11)$ & $99.5(3)$ \\
\hline $\mathrm{O}(3)-\mathrm{Sn}(1)-\mathrm{C}(11)$ & $87.68(10)$ & $\mathrm{O}(7)-\mathrm{Sn}(2)-\mathrm{C}(31)$ & $88.15(10)$ & $92.6(2)$ \\
\hline $\mathrm{N}(1)-\mathrm{Sn}(1)-\mathrm{C}(10)$ & $99.48(11)$ & $\mathrm{N}(2)-\mathrm{Sn}(2)-\mathrm{C}(30)$ & $99.28(11)$ & $108.4(2)$ \\
\hline $\mathrm{N}(1)-\mathrm{Sn}(1)-\mathrm{C}(11)$ & $99.26(0)$ & $\mathrm{N}(2)-\mathrm{Sn}(2)-\mathrm{C}(31)$ & $104.03(11)$ & $118.4(2)$ \\
\hline $\mathrm{C}(10)-\mathrm{Sn}(1)-\mathrm{C}(11)$ & $160.20(12)$ & $\mathrm{C}(30)-\mathrm{Sn}(2)-\mathrm{C}(31)$ & $155.81(13)$ & $133.0(3)$ \\
\hline
\end{tabular}


Table 6. Hydrogen bonding geometry $\left(\AA,^{\circ}\right)$ for complexes $\mathbf{2}, \mathbf{3}$, and $\mathbf{5}$

\begin{tabular}{llllll}
\hline Compound & $\mathrm{D}-\mathrm{H} \cdots \mathrm{A}$ & $\mathrm{D}-\mathrm{H}$ & $\mathrm{H} \cdots \mathrm{A}$ & $\mathrm{D} \cdots \mathrm{A}$ & $\mathrm{D}-\mathrm{H} \cdots \mathrm{A}$ \\
\hline $\mathbf{2}$ & $\mathrm{O}(4)-\mathrm{H}(41) \cdots \mathrm{O}\left(3^{\mathrm{i}}\right)$ & $0.816(10)$ & $1.858(11)$ & $2.670(3)$ & $174(5)$ \\
& $\mathrm{O}(4)-\mathrm{H}(42) \cdots \mathrm{O}\left(2^{\mathrm{ii}}\right)$ & $0.815(10)$ & $1.906(15)$ & $2.702(3)$ & $165(4)$ \\
& $\mathrm{N}(1)-\mathrm{H}(1) \cdots \mathrm{O}(3)$ & $0.837(10)$ & $2.04(2)$ & $2.684(3)$ & $133(3)$ \\
& & & & \\
$\mathbf{3}$ & $\mathrm{O}(4)-\mathrm{H}(41) \cdots \mathrm{O}\left(7^{\mathrm{iii}}\right)$ & $0.84(5)$ & $1.89(5)$ & $2.717(3)$ & $169(4)$ \\
& $\mathrm{O}(4)-\mathrm{H}(42) \cdots \mathrm{O}\left(6^{\mathrm{iv}}\right)$ & $0.85(4)$ & $1.90(4)$ & $2.753(3)$ & $175(4)$ \\
& $\mathrm{O}(8)-\mathrm{H}(81) \cdots \mathrm{O}\left(2^{\mathrm{v}}\right)$ & $0.90(6)$ & $1.90(6)$ & $2.796(3)$ & $175(5)$ \\
& $\mathrm{O}(8)-\mathrm{H}(82) \cdots \mathrm{O}\left(3^{\mathrm{vi}}\right)$ & $0.83(7)$ & $2.02(7)$ & $2.778(3)$ & $152(7)$ \\
& & & & & \\
$\mathbf{5}$ & $\mathrm{O}(3)-\mathrm{H}(1) \cdots \mathrm{N}(1)$ & $1.28(7)$ & $1.36(7)$ & $2.549(5)$ & $150(6)$ \\
\hline
\end{tabular}

Primed atoms refer to atoms from the next symmetrically-related ligand in the polymeric chain (symmetry codes: ${ }^{\mathrm{i}} x, 1+y, z$; ii $1-x, \frac{1}{2}+y, 1-z ;{ }^{\text {iii }} 1-x, \frac{1}{2}+y, \frac{1}{2}-z ;{ }^{\text {iv }}-x, \frac{1}{2}+y, \frac{1}{2}-z ;{ }^{\mathrm{v}} 1-x,-\frac{1}{2}+y, \frac{1}{2}-$ $\left.z ;{ }^{\text {vi }}-x,-\frac{1}{2}+y, \frac{1}{2}-z\right)$. 
Table 7. $\mathrm{LC}_{50}$ values (ppm) of the tribenzyltin(IV) complexes $\mathbf{2}$ and $\mathbf{5}$ along with their triphenyltin(IV) analogs ${ }^{\mathrm{a}} \mathbf{6}$ and 7 against the second instar stage of An. Stephensi mosquito larvae

\begin{tabular}{lcc}
\hline Complex & An. stephensi \\
\hline$\left[\mathrm{Bz}_{3} \mathrm{SnL}^{1} \mathrm{H} . \mathrm{H}_{2} \mathrm{O}\right](\mathbf{2})$ & $14.2 \pm 1.4$ \\
{$\left[\mathrm{Ph}_{3} \mathrm{SnL}^{1} \mathrm{H}\right]_{\mathrm{n}}{ }^{\mathrm{b}}$} & $(\mathbf{6})$ & $6.88 \pm 1.2$ \\
{$\left[\mathrm{Bz}_{3} \mathrm{SnL}^{3} \mathrm{H}\right]_{\mathrm{n}}$} & $(\mathbf{5})$ & $15.3 \pm 0.9$ \\
{$\left[\mathrm{Ph}_{3} \mathrm{SnL}^{3} \mathrm{H}\right]_{\mathrm{n}}^{\mathrm{b}}$} & $(\mathbf{7})$ & $5.2 \pm 0.1$ \\
\hline
\end{tabular}

${ }^{\mathrm{a}}$ Refer to Scheme 1 for ligand description.

${ }^{\mathrm{b}}$ Included for comparison; see ref. 21. 


\section{For supplementary materials}
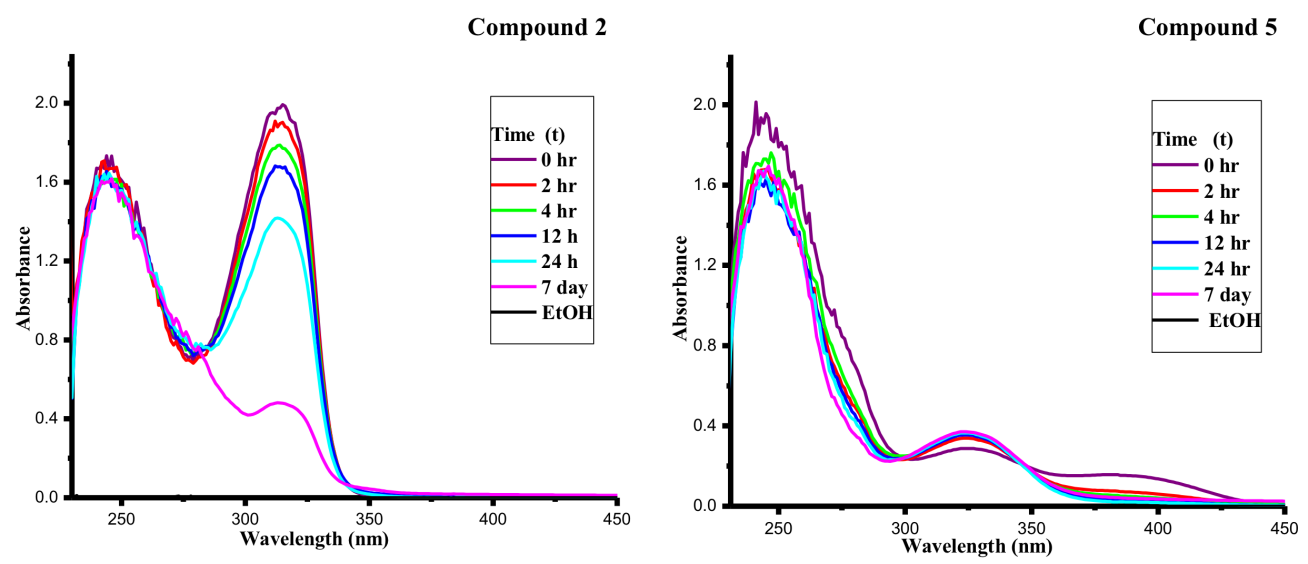

Figure S1 Uv-Vis absorption spectra over time for tribenzyltin(IV) complexes $\left[\mathrm{Bz}_{3} \mathrm{SnL}^{1} \mathrm{H} . \mathrm{H}_{2} \mathrm{O}\right] \mathbf{2}$ and $\left[\mathrm{Bz}_{3} \mathrm{SnL}^{3} \mathrm{H}\right]_{\mathrm{n}} \mathbf{5}$ in $95 \%$ ethanol.

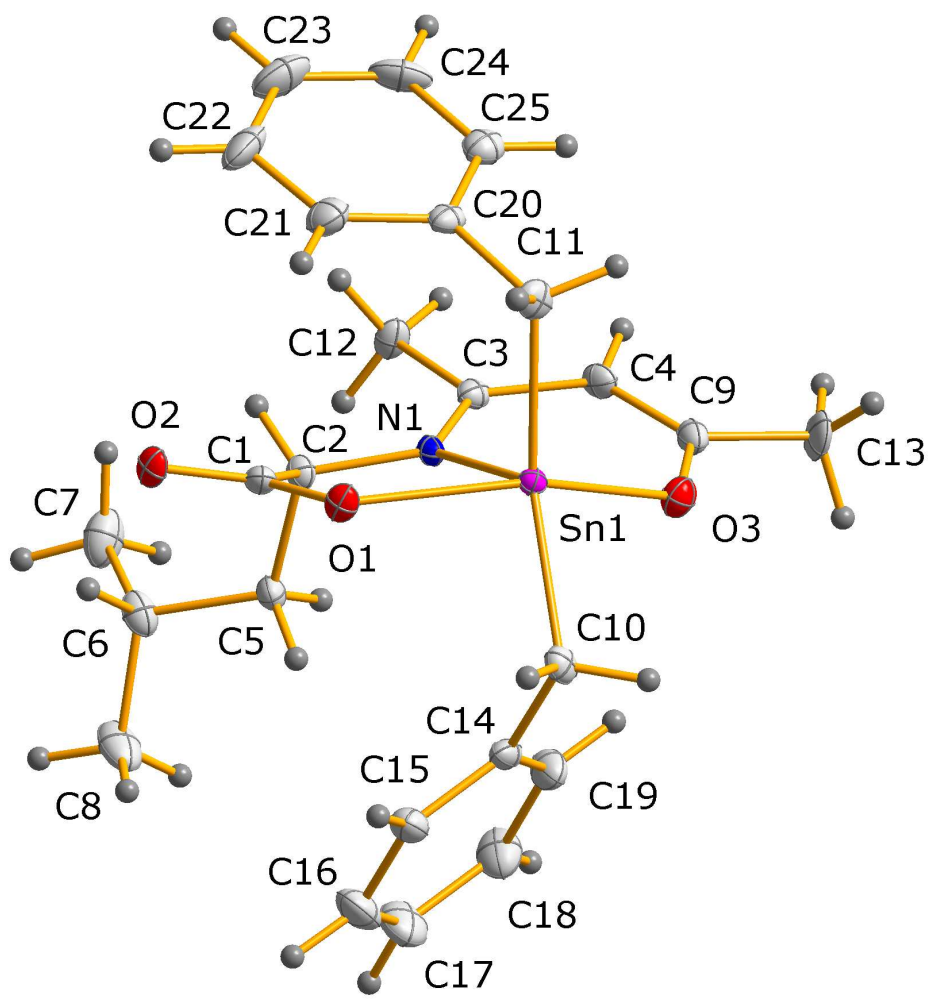

Figure S2 Perspective view of the asymmetric unit of $\mathrm{Bz}_{2} \mathrm{SnL}^{1} \mathbf{1}$ with the atom-labelling scheme (50\% probability ellipsoids). 


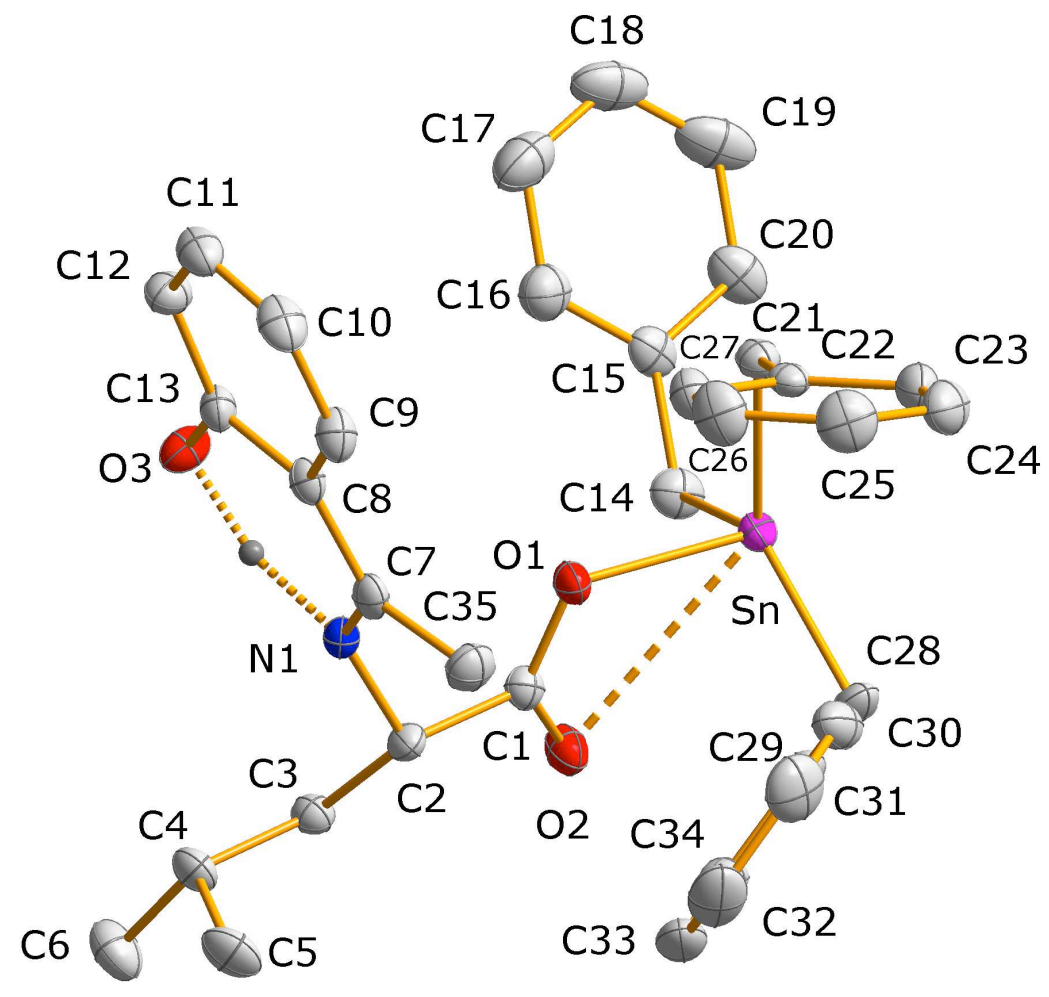

Figure S3 Perspective view of the asymmetric unit of $\mathrm{Bz}_{3} \mathrm{SnL}^{3} \mathrm{H} 5$ with the atom-labelling scheme (50\% probability ellipsoids). Most hydrogen atoms have been omitted for clarity. 


\section{Captions to Scheme and Figures}

Scheme 1. The general representation of potassium salts $\left(\mathrm{L}^{1} \mathrm{HK}-\mathrm{L}^{3} \mathrm{HK}\right)$ with numbering protocol and their organotin(IV) compounds 1-5 illustrating chirality as observed in structural models.

Figure 1. Three repeating units of the crystallographically and chemically unique unit in the polymeric $\left[\mathrm{Bz}_{2} \mathrm{SnL}^{1}\right]_{n}$ chain structure of $\mathbf{1}$. H-atoms omitted for clarity. Symmetry operators: ' 1-x, $\frac{1}{2}+\mathrm{y}, 2-\mathrm{z} ;$ " 1-x, $-\frac{1}{2}+\mathrm{y}, 2-\mathrm{z}$

Figure 2. Molecular structure of $\left[\mathrm{Bz}_{3} \mathrm{SnL}^{1} \mathrm{H} \cdot \mathrm{H}_{2} \mathrm{O}\right] 2$ with atom-labelling scheme $(30 \%$ probability ellipsoids). Most $\mathrm{H}$-atoms omitted for clarity.

Figure 3. The molecular packing of $\mathbf{2}$ viewed down the $a$-axis showing the water ligand involved in two intermolecular hydrogen bonds (dashed lines), which link the molecules into double-stranded chains extending along the [010] direction. Most $\mathrm{H}-$ atoms omitted for clarity.

Figure 4. Three repeats of the crystallographically and chemically unique unit in the polymeric $\left[\mathrm{Bz}_{3} \mathrm{SnL}^{3} \mathrm{H}\right]_{n}$ chain structure of $\mathbf{5}$. Symmetry operators: ' -x, $\frac{1}{2}+\mathrm{y}, \frac{1}{2}-\mathrm{z} ;$ " -x, $-\frac{1}{2}+\mathrm{y}, \frac{1}{2}-\mathrm{z}$. H-atoms omitted for clarity.

Figure 5. Molecular structure of $\left[\mathrm{Me}_{2} \mathrm{SnL}^{3}\right] 4$ with atom-labelling scheme (30\% probability ellipsoids).

Figure 6. A view of the one of the symmetry-independent molecules (Molecule A) of $\left[\mathrm{Me}_{2} \mathrm{SnL}^{2} \cdot \mathrm{H}_{2} \mathrm{O}\right] 3$ showing the atom-labeling scheme (50\% probability ellipsoids).

Figure 7. The molecular packing of $\mathbf{3}$ showing the water ligand in molecule A involved in intermolecular hydrogen bonds (dashed lines) with the carbonyl O-atom in a neighboring molecule $\mathrm{B}$ and with the phenoxide $\mathrm{O}$-atom of a different molecule $\mathrm{B}$ which link the molecules into extended double-bridged chains extending along the 
[100] direction. Symmetry operators: ' -x, $\frac{1}{2}+y, \frac{1}{2}-\mathrm{z} ; \quad$ " $1-\mathrm{x}, \frac{1}{2}+\mathrm{y}, \frac{1}{2}-\mathrm{z} ; \quad$ "' $1+\mathrm{x}, \mathrm{y}, \mathrm{z}$. Most H-atoms omitted for clarity.

\section{Supplementary materials}

Figure S1 Uv-Vis absorption spectra over time for tribenzyltin(IV) complexes $\left[\mathrm{Bz}_{3} \mathrm{SnL}^{1} \mathrm{H} . \mathrm{H}_{2} \mathrm{O}\right] 2$ and $\left[\mathrm{Bz}_{3} \mathrm{SnL}^{3} \mathrm{H}\right]_{\mathrm{n}} \mathbf{5}$ in $95 \%$ ethanol.

Figure S2 Perspective view of the asymmetric unit of $\mathrm{Bz}_{2} \mathrm{SnL}^{1} \mathbf{1}$ with the atom-labelling scheme (50\% probability ellipsoids).

Figure S3 Perspective view of the asymmetric unit of $\mathrm{Bz}_{3} \mathrm{SnL}^{3} \mathrm{H} 5$ with the atom-labelling scheme (50\% probability ellipsoids). Most hydrogen atoms have been omitted for clarity. 